\title{
Hava Savunma Sanayinde Yatırım Projelerinin Çok Ölçütlü Karar Verme ve Hedef Programlama ile Seçimi
}

\author{
Bahri UÇAKCIOĞLU' ${ }^{1}$ Tamer EREN ${ }^{2 *}$ \\ ${ }^{1}$ TUSAŞ-Türk Havacılık ve Uzay Sanayi A.Ş., Kahramankazan-Ankara \\ ${ }^{2}$ Mühendislik Fakültesi, Endüstri Müh. Bölümü, Kırıkkale Üniversitesi, Yahşihan-Kırıkkale
}

\begin{abstract}
Özet
Savunma sanayi alanındaki gelişmeler ve bu doğrultuda yapılan yatııım harcamaları ülkelerin savunma alanındaki konumunu göstermektedir. Ülke ekonomisi içerisinde savunma sanayi yatırım harcamaları önemli bir paya sahiptir. Bu kapsamda yatııım kararı sürecinde en uygun yatırım projesinin seçimi de önem arz etmektedir. Hatalı yatırım projesi veya projelerinin seçimi sonrasında kaynaklar boşa harcanmakta ve kuruluşlar da zarar etme boyutuna gelmektedir. $\mathrm{Bu}$ çalışmada, havacılık savunma sanayinde faaliyet gösteren işletme için yatırım yapılabilecek projeler arasından optimum yatırım projelerinin seçimi için çok ölçütlü karar verme yöntemlerinden analitik hiyerarşi süreci (AHS) ve VIKOR yöntemleri kullanılmış; ayrıca hedef programlama ile matematiksel model kurulmuştur. Yatırım projesi seçiminde bütçe, personel sayısı, bağımlılık durumu, proje süresi, ekonomiye katkı kriterleri uygulamaya dahil edilmiştir. AHS yöntemi ile kriterlerin ve alternatiflerin ağırlıkları elde edilmiştir. Elde edilen ağılıklar VIKOR yönteminde sıralamanın yapılması için kullanılmıştır. Hedef programlama ile de matematiksel model kurulmuştur. AHS yönteminde elde edilen ağırlıklar ve VIKOR yönteminde bulunan sıralama değerleri matematiksel modelde kullanılmıştır. Ayrıca matematiksel modelde birtakım kısıtlar çözüme katılmıştır. Farklı senaryolar matematiksel model üzerinde uygulanmıştır. Böylece karar vericiye alternatif yatırım projeleri arasından optimum projelerin belirlemesinde yol gösterilmesi sağlanmıştır.
\end{abstract}

Anahtar Kelimeler: Yatırım Projesi Seçimi, Çok Ölçütlü Karar Verme, Analitik Hiyerarşi Süreci, VIKOR, Hedef Programlama

\section{Selection of Investment Projects in Air Defense Industry by Multi Criteria Decision Making and Goal Programming}

\begin{abstract}
The developments within defense industry and the investment expenditure made in this region points out the situation of the countries' defensive status. Defense industry investment expenditure have an important share within the country's economy. Therefore, the choice of the most appropriate investment project is also important in the investment determination process. When a wrong desicion is choosed, the resources are wasted, and the foundations have an attitude of loss. In this study, analytical hierarchy process and VIKOR methods were used for multi-criteria decision-making methods for selection of optimum investment projects among the projects that can be invested for the company operating in aviation defense industry; Mathematical model was also established with goal programming. In the selection of the investment project budget, the number of personnel, dependency status, project duration, and economy contribution criteria were included in the application. Ratio of criteria and alternatives were obtained by the AHP method. The obtained ratio was used for ranking in the VIKOR method. A mathematical model was also established with goal programming. The ratio obtained in the AHP method and the ranking values in the VIKOR method were used in the mathematical model. In mathematical model, some constraints are solved. Different scenarios were used on mathematical models. Thus, the decision maker was guided to the determinate optimum projects among alternative investment projects.
\end{abstract}

Keywords: Investment Project Selection, Multi-Criteria Decision Making, Analytic Hierarchy Process, VIKOR, Goal Programming

*Sorumlu Yazar: Doç. Dr. Tamer EREN e-mail: tamereren@gmail.com 


\section{Giriş}

Uluslararası sahada, ülkelerin ekonomik, siyasal ve askeri alandaki kuvvetini belirleyen öğelerden birisi olan savunma sanayinde, dünyada yaşanan teknolojik gelişmeler ve buna bağlı olarak değişimlere, yeniliğe ve modernizasyona devamlı olarak ihtiyaç duyulmaktadır. Ülke savunması gibi önemli bir konuyla doğrudan ilgisi ve uluslararası sahadaki belirleyici rolü, savunma sanayi sektörünün diğer sektörlerden farklı olduğunu göstermektedir. Savunma sanayi işletmeleri uzun sürede, rekabet gücünü koruyabilmesi ve varlığını sürdürebilmesi amaciyla, bilgi teknolojileri öncelikli olmak üzere bilgi altyapılı alanlarda, bilgi ve teknoloji yoğun olan özgün ürünler geliştirmeli ve üretmelidir.

Havacılık savunma sanayi de savunma sanayi sektörü içerisinde yer almaktadır. Diğer savunma sanayi dallarında olduğu gibi havacılık savunma sanayi de, risk ve belirsizlik içermekte olup büyük finansal kaynak ve yatırım gerektirmektedir. Finansal kaynakların yatırımlar arasında bölüştürülmesi veya bir tek yatırıma aktarılması işletmenin gelecek dönemleri açısından hayati öneme sahiptir. Hatalı bir yatırıma aktarılan finansal kaynaklar, işletmeleri geri dönüşü imkânsız veya zor bir duruma sürükleyebilmektedir. Dünyanın küreselleşmesi işletmeler arasındaki rekabeti artırmaktadır. İşletmelerin bu rekabet ortamında yatırım kararlarını seri bir şekilde alması ve hızlı bir şekilde hayata geçirmesi, avantaj elde etmelerini sağlayabilmektedir.

Yatırım kararların alınmasında, yatırımın veya yatırımların birbiri arasında ve kriterler arasındaki bağımlılıkları göz önüne alınması doğru ve yararlı sonuçların elde edilmesini sağlamakta bu da işletmelerin amaçları doğrultusunda yatırım yapmasını imkân tanımaktadır. Yatırım kararlarının alınmasından sonra sıradaki aşama kararların uygulamaya konulmasıdır. Bu aşamada işletmeler bütçe, arz, talep, kapasite, verimlilik ve zaman gibi kriterleri göz önünde bulundurması gerekmektedir. İşletmeler aldıkları yatırım kararının uygulanması aşamasından alınan sonuçlar, işletmelerin karar almadaki başarısını, elde edilen firsatları, yeni ekonomik değerlerin kazanılıp kazanılmadığını göstermektedir. Yatırım kararların etkin olup olmadığ1 da hedeflenen sonuçlara ulaşılıp ulaşılmadığıyla ölçülebilir.

Bu çalışmada hava savunma sanayi sektöründe Ankara ilinde faaliyetini yürütmekte olan bir işletmede yatırım projesi seçimi problemi ele alınmıştır. Problemin çözümünde çok ölçütlü karar verme yöntemlerinden olan AHS ve VIKOR yöntemleri kullanılarak, hedef programlama yöntemi ile matematiksel model kurulmuştur. Çalışma altı bölümden oluşmaktadır. Yatırım projesi seçimi hakkında bilgilere ikinci bölümde değinilmiştir. ÇÖKV, AHS, VIKOR ve Hedef Programlama yöntemleri üçüncü bölümde anlatılmıştır. Literatürde yapılmış olan çalışmalara dördüncü bölümde yer verilmiştir. Beşinci bölümde ise uygulama işletmemizdeki yatırım projesi seçimi için AHS, VIKOR ve Hedef Programlama yöntemleri uygulanmıştır. Uygulamada elde edilen sonuçlar karşılaştırılarak, değerlendirilmesi altıncı bölümde yapılmıştır.

\section{Yatırım Projesi Seçimi}

Proje, bitiş zamanı belirli olmakla birlikte bağımsız şekilde sürdürülebilir hale getirilmiş olan planlardır. Yatırım projesi de, belirli bir amaca ulaşmak için uygun kaynakları kullanarak, belirli süre ve maliyet sinırları içinde tamamlanması gereken faaliyetler olarak tanımlanmaktadır. Yeni bir ürün üretmek için tesis kurulması, kapasite artış1 için yeni tezgâhlar satın alınması, yeni teknolojilerin transfer edilmesi yatırım projeleri kapsamındadır. Yatırım projeleri, firma çalışanlarının tutarlı bir şekilde verileri toplayıp analiz ettiği bir sistem oluşturarak karar verme sürecinde etkinliği sağlamaktadır. Yatırım projesi seçimi de, bireysel ya da grup yatırım projelerinin değerlendirildiği ve işletmenin hedeflerine ulaşmak için uygulanacak olanların seçildiği süreç olarak tanımlanmaktadır.

İşletmeler yatırım projesi seçimi aşamasında büyük meblağda sermaye, işgücü, kaynak ve zaman harcamaktadır. İşletmenin yanlış yatırım projesi seçimi yaptığında kısıtlı finansal kaynak ile birden fazla yatırım projesi seçimi yapılabilecekken bir yatırım projesine tüm bütçe aktarılabilmekte ve büyük meblağlarda zararlara neden olabilmektedir. Üretim hattı açısından ise üretimde gecikmeye yol açacak ve de kayıpların en üst seviyesinde bulunan 
müşteri kaybına da yol açabilecektir. Proje seçiminde kısıtlı olan kaynakların doğru yerlere aktarılması büyük bir öneme sahiptir [1]. Yatırım projesi seçimi kararı yöneticilerin aldığ 1 en önemli kararlardan biridir. İşletmenin hedefini yansıtan yatırım projesinin seçilmesi önemli başarı faktörlerinden biridir. Yatırım projelerinin işletmelerin hedef ve amaçları doğrultusunda seçilmesi önem arz etmektedir. Yatırım projesi seçimindeki verilecek olan kararların tutarlı olabilmesi için seçime elverişli tüm alternatifler ve kriterler net olarak belirlenmelidir. $\mathrm{Bu}$ bilgiler 1şığında sağlıklı seçim yapma imkânına ulaş1labilecektir.

$\begin{array}{cccr}\text { Yatırım } & \text { kararları alınırken } & \text { bilimsel } \\ \text { yöntemlerden } & \text { faydalanılması, } & \text { işletme } \\ \text { yöneticilerinin } & \text { isabetli } & \text { kararlar } & \text { almasını }\end{array}$
sağlamaktadır. Yatırım projelerinin seçimi için çeşitli bilimsel teknikler geliştirilmiştir. Birçok karar verme durumu ile karşı karşıya kalındığında kullanılan yöntemlerden olan çok ölçütlü karar verme yöntemleri, yatırım projesi seçimi uygulamalarında da kullanılmaktadır. Yoğun matematik işlemleri gerektiren bu yöntemlerin uygulanması ile elde edilen çıktılara göre, yatırım projelerinin seçilip seçilmemesi hakkında kararlar verilmekte, bunlar arasındaki öncelik sırası belirlenmekte ve en uygun projenin seçimi yapılmaktadır. Bilimsel yöntemler kullanılırken işletmenin amacını yansıtacak birtakım kriterleri yerine getiren projeler seçilmelidir. İşletmeler yatırım yapma kararı verirken, sahip oldukları kısıtl1 finansal kaynağ 1 kullanarak, yatırım projeleri alternatifleri arasından bir seçim yaparak ve belirlemiş olduğu hedefe ulaşabilecek optimal sonuca ulaşabilmeyi hedeflemektedir. Seçimi yapılacak yatırım projeleri birbirleri ve kriterleri arasında bağımlılığı göz önüne alınarak yapıldığında daha doğru ve yararlı sonuçlar elde edilerek işletmelere büyük faydalar sağlamaktadır.

\section{Yöntemler}

Çok ölçütlü karar verme, AHS, VIKOR ve hedef programlama hakkında açıklamalar bu bölümde yer almaktadır.

\section{Çok Ölçütlï Karar Verme}

Dünyanın küreselleşmesi ile birlikte, işletmeler kar marjlarını yükseltmek, maliyetlerini azaltmak, müşteri kitlelerini artırmak ve bunlara bağlı olarak da ürünlerinin kalitelerini artırmak veya daha kaliteli hizmet vermek için bulunulan rekabet ortamında devamlı kararlar vermek durumunda kalmaktadirlar. Verilmekte olan bu kararlar, bulunulan çevreden, pazardan toplanan birçok bilgiye göre alınmakta olduğundan bilginin toplanması için işletmeler bir takım yatırımlar gerçekleştirmektedir. Bilgiyi toplamak, düzenlemek, gelişen rekabet ortamına uyum sağlamak, kaliteyi yükseltmek, taleplere yetişebilmek ve memnuniyeti sağlamak amacı ile problemlerin vakit kaybı olmadan ve doğru önem sırası ile çözümlenmesi gerekmektedir. Karar verme aşamasında birçok alternatif arasından seçimler yapılmaktadır. Karar verme sürecinde önemli olan üç unsur bulunmaktadır. Bunlar; karar verici, alternatifler ve kriterlerdir.

Yapılan araştırmalar, günlük alınan pek çok kararın sezgisel olarak alınmasının yeterli olmasına rağmen, karmaşık ve hayati kararlar için bu yolun tek başına yeterli olmadığını göstermektedir [2]. Çok ölçütlü karar verme, karar vericinin sayılabilir sonlu ya da sayılamaz sayıda seçenekten oluşan bir küme içinde en az iki kriter kullanarak yaptığı seçim işlemi ya da diğer bir deyişle, iki veya daha çok kritere dayalı değerlendirme yaparak alternatifler arasından seçim yapma işlemi olarak tanımlanabilir [3]. Çok ölçütlü karar vermede hangi yöntem ya da teknik kullanılırsa kullanılsın insan karar verme sürecinin en önemli bileşenini teşkil etmektedir. Bu hususta çok ölçütlü karar verme yöntemleri karar vericilere en uygun karara ulaşabilmeleri için yardımcı olan bir araç niteliğindedirler [4].

Çok ölçütlü karar verme yöntemlerinin kullanım alanı yaygındır. $\mathrm{Bu}$ yöntemlerden olan AHS ve VIKOR yöntemlerine değinilmiştir.

\section{Analitik Hiyerarși Süreci}

Analitik Hiyerarşi Süreci (AHS), karar verme ile ilgili problemlerin çözümü safhasında en fazla kullanılmakta olan bir yöntemdir. Yapılandırılmamış ve karmaşı kararlar ile başa çıkma süreci üzerine geliştirilen ve karar verme 
problemlerinin çözümünde kullanılan AHS 1970'lerde Saaty tarafindan kullanılan bir tekniktir [5]. AHS, homojen elemanların ortak bir kriter veya niteliğe göre ikili karşılaştırmalardan baskın önceliklerin türetilmesiyle ilgili bir ölçüm teorisidir [6]. AHS; karar vericinin tüm kriterlerini yakalayan en iyi alternatifi seçmekle, "Hangisini seçeceğiz?" veya "En iyisi hangisidir?" sorularına cevap bulur [7]. AHS yöntemi, insanın doğal düşüncelerini açık bir sürece dönüştürmek amaciyla nicel ve nitel yönleri benzersiz bir analiz yapısını içerir. Sonucunda farkl1 senaryolar altında olsa bile, objektif ve güvenilir sonuçları sunan karar destek araçları uygulanır. Önceliklendirmeyi yapanın öznel algılamasının olması, AHS yönteminde, "daima doğru, değişmez" kararının olası varlığ anlamına gelmez [8]. AHS'nin uygulama alanı çok geniş olup etkin çözümler sunmaktadır.

AHS yöntemi uygulama aşamaları aşağıda açıklanmıştır.

Aşama-1: Problem tanımlanarak karar vericinin ulaşmak isteği hedef belirlenir.

Aşama-2: Çözüme etki edecek olan kriterler belirlenir.

Aşama-3: Çözümde kullanılacak alternatifler belirlenir.

Aşama-4: Hedeften başlanarak, kriterler ve alternatifler arasında hiyerarşik yapı oluşturulur.

Aşama-5: Kriterlerin kendi arasındaki, alternatiflerinde kriterler arasındaki ikili karşılaştırma matrisleri (nxn) boyutunda oluşturulur ve ikili karşılaştırmalar yapılır. Kriter ve alternatifler arasında ikili karşılaştırmaların yapılması için kullanılan önem skalası Tablo 1'de verilmiştir [9].

Aşama-6: İkili karşılaştırma matrisinde her bir sütundaki değerin ilgili sütun toplamına bölünmesiyle normalize matris elde edilir.

Aşama-7: Normalize edilmiş olan matrisin satır değerlerinin aritmetik ortalamasının alınması ile her bir kriterin ve alternatifin öz vektör yani öncelik vektör matrisi elde edilir.

Așama-8: Aşama-7'de bulunan öncelik vektörü matrisi ile Aşama-5'te hazırlanmış olan ikili karşılaştırma matrisinin çarpılması sonucu sütun vektör matrisi elde edilir.

Tablo 1. Önem Skalası

\begin{tabular}{cl}
\hline $\begin{array}{c}\text { Önem } \\
\text { Değerleri }\end{array}$ & \multicolumn{1}{c}{ Değer Tanımları } \\
\hline 1 & Eşit Önemde \\
3 & Biraz Daha Önemli (Az Üstünlük) \\
5 & Oldukça Önemli (Fazla Üstünlük) \\
7 & Çok Önemli (Çok Üstünlük) \\
9 & Son Derece Önemli (Kesin Üstünlük) \\
$2,4,6,8$ & Ara Değerler (Uzlaşma Değerleri) \\
\hline
\end{tabular}

Aşama-9: Sütun vektör matrisinin, Aşama-7'de elde edilen öncelik vektör matrisine bölünmesi ile temel değer elde edilir.

Aşama-10: Aşama-9'da elde edilen temel değerlerin aritmetik ortalamasının alınması ile $\lambda_{\max }$ değeri elde edilir.

Aşama-11: Tutarlılık indeksi aşağıda belirtilen formüle göre hesaplanır.

$\mathrm{CI}=\left(\lambda_{\max }-\mathrm{n}\right) /(\mathrm{n}-1)$

CI: Tutarlılık İndeksi

n: Kriter/Alternatif Sayıs1

Aşama-12: Bir önceki adımda bulduğumuz tutarlılık indeksinin, Tablo 2'de yer alan kriter/alternatif sayısı karşıllı̆ındaki ortalama rassal tutarlılık değerine bölünmesi ile tutarlılık oranı hesaplanır. Tutarlılık oranı aşağıda belirtilen formüle göre hesaplanır.

$\mathrm{CR}=\mathrm{CI} / \mathrm{RI}$

CR: Tutarl1l1k Oranı

RI: Ortalama Rassal Tutarlılık

Tutarlılık oranı 0,10 değerinden küçük olmalıdır. Şayet bulunan tutarlılık oranı 0,10 'dan büyük çıkarsa sonucun tutarlı olmadığını gösterir. $\mathrm{Bu}$ durumda ikili karşılaştırma matrisi tekrar gözden geçirilmeli ve düzeltmelerin sonrasında yukarıdaki adımlar tekrar edilmelidir. 
Aşama-13: Kriterlerin ve alternatiflerin hesaplanmış olan özvektörlerinin aralarında çarpılması ile alternatiflerin önem değerleri belirlenir. Sonuç olarak hedefe ulaşmak için belirlenen kriterler çerçevesinde yüzdelik değeri en yüksek olan alternatifin seçilmesine karar verilir.

Tablo 2. Ortalama rassal tutarlılik (RI) tablosu

\begin{tabular}{cc}
$\mathbf{N}$ & $\mathbf{R I}$ \\
\hline 1 & 0 \\
2 & 0 \\
3 & 0,58 \\
4 & 0,9 \\
5 & 1,12 \\
6 & 1,24 \\
7 & 1,32 \\
8 & 1,41 \\
9 & 1,45 \\
10 & 1,49 \\
\hline
\end{tabular}

\section{VIKOR}

VIKOR (Vlsekriterijumska Optimizacija1 Kompromisno Resenje), karmaşı yapıdaki sistemlerin çok kriterli optimizasyonu için geliştirilmiş olan çok ölçütlü karar verme yöntemidir. VIKOR, farklı kriterlere bağımlı olarak seçilen alternatifler grubundaki unsurların sıralanması ve seçilmesi üzerine yapılandırılmış bir yöntemdir. Uygulamalarda çoğu zaman ölçülemeyen ve birbirlerinden farklı değerlere sahip kriterlerle karşı karşıya kalınır. Aynı zamanda, uygulama için belirlenen çözümü tüm kriterleri aynı anda sağlayamaması da karşılaşılan bir durumdur. $\mathrm{Bu}$ gibi durumlarda VIKOR yöntemi karar vericiye son kararı almasında yardımcı olan uzlaşık çözümü sunar. İlk olarak Yu [10] tarafindan sonra Zeleny [11] tarafindan uzlaşık çözüm tabiri ortaya çıkarılmıştır. Uzlaşık çözüm; ideale en yakın olan, uygulanabilir çözüm olarak da tanımlanabilir. VIKOR yöntemi karmaşı sistemlerin çok kriterli optimizasyonu için 2004 yılında ilk kez Opricovic ve Tzeng tarafından önerilmiştir [12].

Belirlenmiş $m$ adet alternatif $a_{1}, a_{2}, a_{3}, \ldots \ldots, a_{m}$, $\mathrm{n}$ adet kriter $\mathrm{c}_{1}, \mathrm{c}_{2}, \mathrm{c}_{3}, \ldots, \mathrm{c}_{\mathrm{n}}$ ve her bir $\mathrm{a}_{\mathrm{j}}$, $\mathrm{j}=1,2, . ., \mathrm{m}$ alternatifinin $\mathrm{c}_{\mathrm{i}}, \mathrm{i}=1,2,3, \ldots, \mathrm{n}$ kriter karşılığındaki puanı $\mathrm{f}_{\mathrm{ij}}$ olmak üzere VIKOR yönteminin uygulama aşamaları aşağıda açıklanmıştır.

Aşama-1: Tüm kriterler için en iyi $\left(f_{i}^{+}\right)$ve en kötü $\left(f_{i}^{-}\right)$değerler belirlenir. Fayda sağlayan i kriteri için;

$$
f_{i}^{+}=\max _{j} f_{i j} \quad f_{i}^{-}=\min _{j} f_{i j} \quad i=1,2, \ldots, n
$$

Aşama-2: $S_{j}$ ve $R_{j}$ değerleri $j=1,2, \ldots, m$ için hesaplanır.

$S_{\mathrm{j}}=\sum_{i=1}^{n} w_{\mathrm{i}} \frac{\left(f_{\mathrm{i}}^{+}-f_{i j}\right)}{\left(f_{\mathrm{i}}^{+}-f_{i}^{-}\right)}$

$R_{j}=\max _{j}\left[w_{\mathrm{i}} \frac{\left(f_{\mathrm{i}}^{+}-f_{i j}\right)}{\left(f_{\mathrm{i}}^{+}-f_{\mathrm{i}}^{-}\right.}\right]$

Formülde $S_{j} ; j$. alternatif için ortalama grup skorunu, $R_{j} ; j$. alternatif için en kötü grup skorunu göstermektedir. Formüldeki $\mathrm{w}_{\mathrm{i}}$ göreli önemleri gösteren kriter ağılıklarını ifade etmektedir. Ağırlıklar toplamı 1'e eşit olmalıdır.

Aşama-3: $Q_{j}$ değerleri tüm $j=1,2, \ldots, m$ için belirlenir.

$Q_{\mathrm{j}}=\frac{\mathrm{v}\left(S_{j}-\mathrm{S}^{+}\right)}{\left(S^{-}-S^{+}\right)}+\frac{(1-v)\left(\mathrm{R}_{j}-\mathrm{R}^{+}\right)}{\left(R^{-}-R^{+}\right)}$

Burada;

$S^{+}=\min _{j} S_{j} \quad S^{-}=\max _{j} S_{j}$

$R^{+}=\min _{j} R_{j} \quad R^{-}=\max _{j} R_{j}$

Formüldeki v değeri kriterlerin çoğunluğunun ağırlığını yani maksimum grup faydasını ifade etmektedir. Başka bir deyişle; v değeri maksimum grup faydasını sağlayan strateji için ağırlığı ifade ederken, 1-v değeri de karşıt görüştekilerin minimum pişmanlığının ağırlığını ifade etmektedir [13]. Uzlaşma $v>0,5$ ile konsensüs $v=0,5$ ile veto $\mathrm{v}<0,5$ ile sağlanabilmektedir. Uygulamalarda genellikle uzlaşma değeri $\mathrm{v}>0,5$ kullanılır.

Aşama-4: $S_{j}, R_{j}$ ve $Q_{j}$ değerleri artan değere göre sıralanarak alternatifler arasındaki sıralama belirlenir. $\mathrm{Bu}$ oluşturulan liste sonuçları göstermektedir. $\mathrm{O}_{j}$ değeri en küçük olan alternatif en iyi alternatif olarak kabul edilir.

Aşama-5: Sonucun geçerli olarak kabul edilmesi için aşağıdaki iki koşulun sağlanması gerekmektedir. Ancak bu durumda minimum Q 
değerine sahip alternatif en uygun olarak değerlendirilebilir.

Koşul-1 (Kabul edilebilir avantaj):

$\mathrm{DQ}=1 /(\mathrm{m}-1)$

$\mathrm{Q}\left(\mathrm{t}^{\prime \prime}\right)-\mathrm{Q}\left(\mathrm{t}^{\prime}\right) \geq \mathrm{DQ}$

t': Q değerine göre birinci sıradaki alternatif

t": Q değerine göre ikinci sıradaki alternatif

m: Alternatif sayıs 1

Koşul-2 (Kabul edilebilir istikrar):

En iyi $Q$ değerine sahip $t^{\prime}$ alternatifi, $S$ ve $R$ değerlerinin en az birinde en iyi değeri elde etmelidir.

Şayet Koşul-1 ve Koşul-2'den biri sağlanmıyorsa uzlaşık çözüm kümesi şöyledir:

Koşul-2 sağlanmıyorsa, birinci sıradaki t' ve ikinci sıradaki $t$ " alternatiflerinin ikisi de en iyi uzlaşılmış ortak çözüm olarak belirlenir.

Koşul-1 sağlanmıyorsa $t^{\prime}, t^{\prime \prime}, \ldots, t(m)$ alternatifleri ve değeri maksimum $\mathrm{m}$ için $\mathrm{Q}(\mathrm{t}(\mathrm{m}))-\mathrm{Q}\left(\mathrm{t}^{\prime}\right)<\mathrm{DQ}$ ile belirlenir.

Q değerlerine göre siralanan en iyi alternatif, minimum $\mathrm{Q}$ değerine sahip alternatiflerden biridir [12].

\section{Hedef Programlama}

Hedef programlama (HP) çok amaçlı optimizasyonun bir dalıdır. Gerçek hayatta karşılaştığımız birçok problemin yapısında birçok amacımız vardır. $\mathrm{Bu}$ amaçlarımız bazen birbirleriyle paralel olurken bazen de birbirleriyle çatışma içinde olabilir. Her iki durumda da bu amaçlarımızın eş zamanlı sağlanması için çok amaçlı programlama modellerinden yararlanılmaktadır. Bu çok amaçlı programlama modellerinden biri olan hedef programlama, hedeflerin hepsini birer kısıt haline dönüştürür ve önem sırasına göre hedeflerden sapmayı minimize etmeye çalışır [14].

HP üzerine, Charnes ve arkadaşları [15] ilk çalışmayı yapmıştır. HP'nin ilk olarak tanımı Charnes ve Cooper [16] tarafından yapılmıştır. Lee'nin [17] ve İgnizio'nun [18] yapmış olduğu çalışmalar ile uygulamalar ve teknik gelişmeler artış göstermiştir.

Hedef programlamanın matematiksel gösterimi şu şekildedir.

$\operatorname{Min} Z=\left[P_{1} w_{1}\left(d_{1}^{+}, d_{1}^{-}\right)+\ldots .+P_{k} w_{k}\left(d_{k}^{+}, d_{k}^{-}\right)\right.$

$\sum_{j=1}^{n} a_{i j} x_{j}-d_{i}^{+}+d_{i}^{-}=b_{i}$

$d_{i}^{+}, d_{i}^{-}, x_{j} \geq 0 \quad i=1, \ldots, m, \quad j=1, \ldots, n$

Matematiksel gösterimdeki değişkenler;

$\mathrm{x}_{\mathrm{j}}$ : j. karar değişkeni

$\mathrm{a}_{\mathrm{ij}}$ : i. hedefin j. karar değişkeni katsayısı

$b_{i}:$ i. hedef için ulaşılmak istenen değer

n: Karar değişkenleri sayısı toplamı

m: Kisit sayis1 toplamı

$\mathrm{P}_{\mathrm{k}}:$ Öncelik değeri

$\mathrm{W}_{\mathrm{k}}$ : A ̆ğrlık değeri

$d_{i}^{+}:$i. hedefin pozitif sapma değişkeni

$d_{i}^{-}:$i. hedefin negatif sapma değişkeni

\section{Literatürde Yapılan Çalışmalar}

Çalışmada kullanılan yöntemlerle ilgili literatür araştırmasında bu bölümde yer verilmiştir.

Weingartner [19], yatırım projesi seçimi kriterleri üzerine çalışma yapmıştır. Mukherjee ve Bera [20], hedef programlama yöntemini kullanarak kömür madenciliği sektöründe proje seçim kararı üzerinde çalışmışlardır. Santhanamt ve Kyparisis [21], 0-1 hedef programlama ile bilgi sistemi projesi seçimi yapmışlardır. Kim ve Emery [22], Woodward yönetim şirketlerinde uçak kontrol grupları için proje seçiminde 0-1 hedef programlama modelini kullanmışlardır. Lee ve Kim [23], Analitik Ağ Süreci (ANP) ve hedef programlama ile bağımsız bilgi sistemi projesi seçimi konusunda çalışma yapmışlardır. Badri vd. [24], sağlık hizmetleri kurumları için proje seçiminde hedef programlama üzerine çalışma yapmışlardır. Yavuz ve Captain [25], çok dönemli sermaye bütçelemede tamsayılı programlama kullanmışlardır. Aras vd. [26], AHS yöntemi ile rüzgâr gözlem istasyonu yeri seçimi yapmışlardır. 
Cheng ve Li [27], önceliklere göre proje seçimi konusu üzerinde çalışmışlardır. Tzeng vd. [28], seçenek yakıtların değerlendirmesi konusunu ele alarak, VIKOR ve The Technique For Order Preference By Similarity To Ideal Solution (TOPSIS) yöntemlerini kullanmışlardır. Dimova vd. [29], yatırım projelerinin değerlendirilmesi için uygulama yapmışlardır. Yang ve Wang [30], ürün ömrü üzerine yaptıkları çalışmalarında AHS ve VIKOR yöntemlerini kullanmışlardır. Liu ve Yan [31], inşaat projesi tekliflerini değerlendirmek için VIKOR yöntemini ele almışlardır. Tripathy ve Biswal [32], yeni ürün geliştirme projelerinin seçimi için 0-1 hedef programlama yöntemi kullanmışlardır. Kim vd. [33], bilgi sistemi projesi seçiminde ANP ve hedef programlama yöntemlerini kullanarak çalışma yapmışlardır. Gülenç ve Bilgi [34], yeni kapı yatırımı seçimi için AHS yöntemi üzerinde çalışmışlardır. Aragonés-Beltrán vd. [35], ANP yöntemi ile fotovoltaik güneş enerjisi projesi seçimini ele almışlardır. San Cristóbal [36], VIKOR yöntemi ile yenilenebilir enerji projesi seçimi üzerine çalışma yapmıştır. Nandi vd. [37], AHS yöntemini kullanarak inşaat sektöründe proje seçimi yapmışlardır. Kuru ve Akın [38], birden fazla nitel ve nicel kriteri göz önüne alarak en uygun entegre yönetim sisteminin seçimini amaçlamışlardır. $\mathrm{Bu}$ amaca ulaşmak için çok kriterli karar verme tekniklerinden AHS, Elimination and Choice Translating Reality English (ELECTRE) ve VIKOR tekniklerini ayrı ayrı uygulamışlardır. Ebrahimnejad vd. [39], ANP ve VIKOR yöntemlerini kullanarak inşaat projesi seçimi üzerine çalışma yapmışlardır. Bilgen ve Şen [40], otomotiv sektöründe bulanık AHS yöntemini kullanarak proje seçimi yapmıştır. Kaplan ve Arıkan [41], bulanık AHS yöntemi ile tezgâh yatırımı projesi seçimi yapmışlardır. AragonésBeltrán vd. [42], güneş-termal enerji santrali yatırımı projesi seçimi için AHS ve ANP yöntemlerini kullanmışlardır. Dozic ve Kalic [43], AHS yöntemi ile uçak tipi seçimi konusunda çalışma yapmışlardır. Bedir ve Eren [44], perakende sektöründe faaliyet gösteren bir firmanın satış danışmanı seçim probleminde AHS ve PROMETHEE yöntemlerini uygulamışlardır. Karaman ve Çerçioğlu [1], hedef programlama, AHS ve VIKOR yöntemleri ile hastane projeleri seçimi yapmışlardır. Pangsri [45], inşaat sektöründe proje seçimi için AHS ve TOPSIS yöntemlerini kullanmıştır. Salehi [46], proje seçimi için AHS ve VIKOR yöntemlerini kullanmıştır. Eren ve Özder [47], bir içecek firması için tedarikçi seçiminde AHS yöntemini kullanmışlardır. Hamurcu ve Eren [48], Ankara'da monoray rotası seçiminde AHS ve TOPSIS yöntemleri üzerinde çalışma yapmışlardır. Cihan vd. [49], ekokardiyografi cihazı seçiminde AHS yöntemini ele almışlardır. Gür vd. [50], hedef programlama ve AHS yöntemleri ile monoray projelerinin seçimini yapmışlardır. Taş vd. [51], kurulacak olan monoray hattı için alternatif projeler arasından en uygun projenin seçimini AHS ve hedef programlama ile yapmışlardır. Hamurcu ve Eren [52], bulanık AHS ve VIKOR yöntemini birlikte kullanarak kent için ulaşımı için proje seçimi yapmıştır. Uçakcıoğlu ve Eren [53], alternatif projeler arasindan AHS, VIKOR ve hedef programlama yöntemleri ile en uygun projenin seçimini yapmışlardır. Hamurcu ve Eren [54], bulanık ANP yöntemini kullanarak kent içinde kullanılabilir raylı sistem projelerinin önceliklendirilmesini yapmışlardır.

\section{Uygulama}

Dünya havacılık sanayi içerisindeki rekabet koşulları altında faaliyet gösteren şirket, kaliteli, ucuz ve istenilen miktarda ürün üretmek ve yeni ürünler geliştirmek amacındadır. $\mathrm{Bu}$ amacının doğrultusunda müşteri taleplerini zamanında karşılayabilmek için farklı karar verme mekanizmalarına ihtiyaç duymaktadır. Şirketin varlığını sürdürebilmesi için yöneticilerin çok karmaşık problemler karşısında etkili ve doğru karar vermeleri önem arz etmektedir.

Bu çalışmada, Ankara ilinde havacılık sanayinde faaliyet gösteren bir işletmede, önceden belirlenmiş olan yatırım projeleri arasından AHS, VIKOR, hedef programlama ile seçim yapılması amaçlanmıştır.

\section{AHS Yöntemi}

AHS yöntemi çözüm aşamaları aşağıda belirtilmiştir.

Aşama-1: Problemin tanımlanması ve probleme ilişkin hedefin belirlenmesi: Ankara'da faaliyet gösteren savunma sanayi firmasının, yöneticileri ve 
uzman personeli devamlı karar verme ile karşı karşıyadır. Kararların, işletmenin amaçları doğrultusunda verilmesi ve etkin olması önem arz etmektedir. Bu kapsamda ülke savunma sanayii ve işletmenin geleceği için yatırım projesi seçimi kararı verilmesi gerekmektedir.

Aşama-2: Kriterlerin belirlenmesi: Şirkette çalışan 20 yatırım uzmanı ile anket yapılmış olup anket sonuçlarına göre kriterler belirlenmiştir. Yatırım projelerinin değerlendirilmesinde kullanılacak kriterler aşağıdaki belirtilmiştir.

Proje Bütçesi (K1): Projenin gerçekleşmesi için ihtiyaç olan giderdir.

Proje Süresi (K2): Projenin tamamlanabilmesi için gereken süredir.

Bağımlılık Durumu (K3): Projenin şirket içerisinde mi yapılacağı veya dışarından hizmet alımı yoluyla mı yapılacağının göstergesidir.

Personel Sayısı (K4): Projede çalışması gereken personel sayısidır.

Ekonomiye Katk1 (K5): Projenin ülke ekonomisine katkısıdır.

Aşama-3: Alternatiflerin (seçeneklerin) belirlenmesi: Yatırım uzmanlarından alınan bilgiler doğrultusunda 8 adet alternatif (yatırım projesi) belirlenmiştir. Belirlenen yatırım projeleri aşağıda açıklanmıştır.

Proje-1 (P1): AR-GE projeleridir.

Proje-2 (P2): Eğitim uçağ1 tasarımı ve imalatı projesidir.

Proje-3 (P3): Helikopter tasarım ve imalatını kapsayan projedir.

Proje-4 (P4): İnsansız hava arac1 tasarım1, imalatını içeren projedir.

Proje-5 (P5): Nakliye uçağı tasarım, imalat ve geliştirilmesini kapsayan projedir.

Proje-6 (P6): Savaş uçaklarının yapımı, geliştirilmesi gibi aşamaları kapsayan projedir.

Proje-7 (P7): Uydu tasarım, imalat ve geliştirme aşamasını içeren projedir.
Proje-8 (P8): Yolcu taşıma için hava aracı tasarım, geliştirme ve imalatını kapsayan projedir.

Așama-4: Hiyerarșik yapının oluşturulması: Oluşturulan hiyerarşik yapı Şekil 1'de verilmiştir.

Aşama-5: İkili karşılaştırma matrislerinin oluşturulması: Kriterlerin kriterler açısından, alternatiflerinde kriterler açısından ikili karşılaştırma matrisleri oluşturularak aşağıda tablolar halinde verilmiștir.

Kriterlerin kriterler açısından ikili karşılaştırma matrisi Tablo 3'de oluşturulmuştur.

Tablo 3. Kriterlerin Kriterler Açısından İkili Karşılaştırma Matrisi

\begin{tabular}{cccccc} 
Kriterler & K1 & K2 & K3 & K4 & K5 \\
\hline K1 & 1,00 & 2,00 & 3,00 & 2,00 & 0,33 \\
K2 & 0,50 & 1,00 & 1,00 & 2,00 & 0,50 \\
K3 & 0,33 & 1,00 & 1,00 & 0,20 & 0,14 \\
K4 & 0,50 & 0,50 & 2,00 & 1,00 & 0,17 \\
K5 & 3,00 & 2,00 & 7,00 & 6,00 & 1,00
\end{tabular}

Alternatiflerin proje bütçesi kriteri açısından ikili karş1laştırma matrisi Tablo 4'de verilmiştir.

Tablo 4. Alternatiflerin Proje Bütçesi Kriteri Açısından İkili Karşılaştırma Matrisi

\begin{tabular}{ccccccccc}
\hline Alternatifler & P1 & $\mathbf{P 2}$ & $\mathbf{P 3}$ & $\mathbf{P 4}$ & $\mathbf{P 5}$ & $\mathbf{P 6}$ & $\mathbf{P 7}$ & $\mathbf{P 8}$ \\
$\mathbf{P 1}$ & 1,00 & 2,00 & 0,11 & 0,11 & 0,33 & 0,11 & 1,00 & 2,00 \\
$\mathbf{P 2}$ & 0,50 & 1,00 & 0,20 & 0,20 & 0,33 & 0,14 & 0,50 & 1,00 \\
$\mathbf{P 3}$ & 9,00 & 5,00 & 1,00 & 1,00 & 5,00 & 0,50 & 9,00 & 5,00 \\
$\mathbf{P 4}$ & 9,00 & 5,00 & 1,00 & 1,00 & 5,00 & 1,00 & 9,00 & 5,00 \\
P5 & 3,00 & 3,00 & 0,20 & 0,20 & 1,00 & 0,14 & 3,00 & 3,00 \\
P6 & 9,00 & 7,00 & 2,00 & 1,00 & 7,00 & 1,00 & 9,00 & 7,00 \\
P7 & 9,00 & 7,00 & 2,00 & 0,50 & 5,00 & 0,50 & 9,00 & 7,00 \\
P8 & 1,00 & 2,00 & 0,11 & 0,11 & 0,33 & 0,11 & 1,00 & 2,00 \\
\hline
\end{tabular}




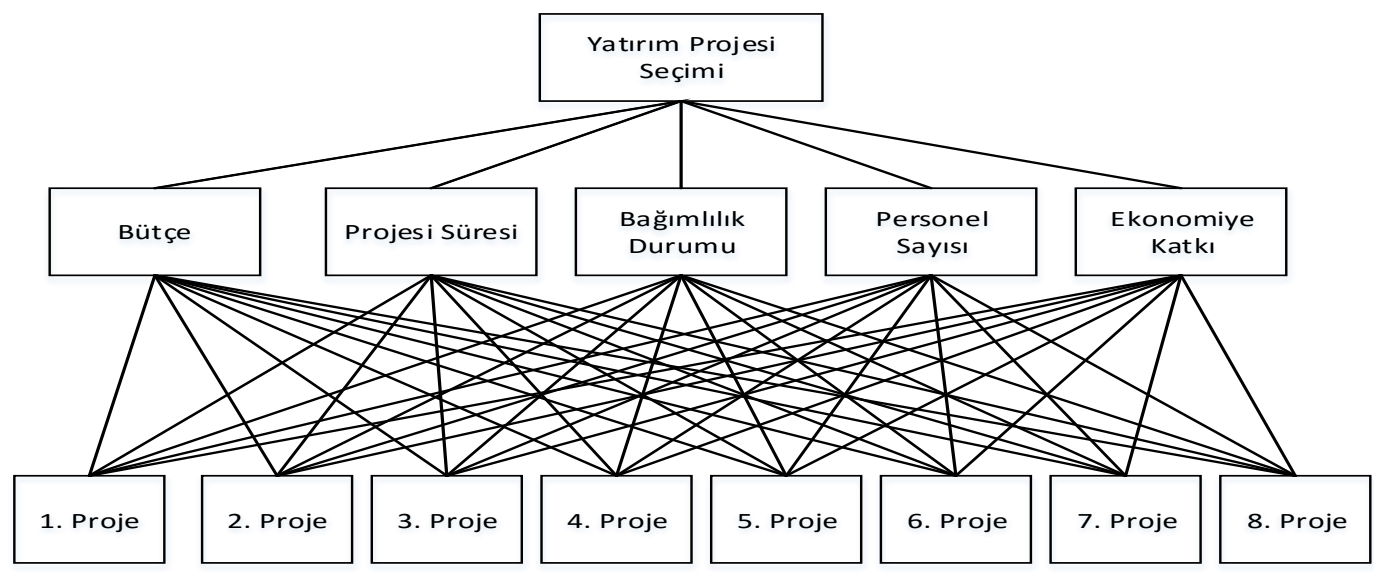

Şekil 1. Hiyerarşik Yap1

Tablo 5. Alternatiflerin Proje Süresi Kriteri Açısından İkili Karşılaştırma Matrisi

\begin{tabular}{ccccccccc}
\hline Alternatifler & P1 & P2 & P3 & P4 & P5 & P6 & P7 & P8 \\
\hline P1 & 1,00 & 0,50 & 0,14 & 0,14 & 0,33 & 0,11 & 1,00 & 0,50 \\
P2 & 2,00 & 1,00 & 0,25 & 0,17 & 0,50 & 0,13 & 2,00 & 1,00 \\
P3 & 7,00 & 4,00 & 1,00 & 0,33 & 3,00 & 0,33 & 7,00 & 4,00 \\
P4 & 7,00 & 6,00 & 3,00 & 1,00 & 5,00 & 1,00 & 7,00 & 6,00 \\
P5 & 3,00 & 2,00 & 0,33 & 0,20 & 1,00 & 0,13 & 3,00 & 2,00 \\
P6 & 9,00 & 8,00 & 3,00 & 1,00 & 8,00 & 1,00 & 9,00 & 8,00 \\
P7 & 7,00 & 7,00 & 2,00 & 0,20 & 7,00 & 0,50 & 7,00 & 7,00 \\
P8 & 1,00 & 0,50 & 0,14 & 0,14 & 0,33 & 0,11 & 1,00 & 0,50 \\
\hline
\end{tabular}

Alternatiflerin proje süresi kriteri açısından ikili karşılaştırma matrisi Tablo 5'de verilmiştir.

Alternatiflerin bağımlılık durumu kriteri açısından ikili karşılaştırma matrisi Tablo 6'da verilmiştir.

Alternatiflerin personel sayısı kriteri açısından ikili karşılaş̧ırma matrisi Tablo 7'de verilmiştir.

Alternatiflerin ekonomiye katkı kriteri açısından ikili karşılaştırma matrisi Tablo 8'de verilmiştir.

Aşama-6: Normalize matrisinin oluşturulması: Kriterlerin kriterler açısından, alternatiflerinde kriterler açısından ikili karşılaştırma matrislerinden elde edilen normalize matrisler aşağıda tablolar halinde verilmiştir.
Tablo 6. Alternatiflerin Bağımlılık Durumu Kriteri Açısından İkili Karşılaştırma Matrisi

\begin{tabular}{ccccccccc}
\hline Alternatifler & P1 & P2 & P3 & P4 & P5 & P6 & P7 & P8 \\
\hline P1 & 1,00 & 3,00 & 1,00 & 3,00 & 2,00 & 0,50 & 1,00 & 3,00 \\
P2 & 0,33 & 1,00 & 2,00 & 0,33 & 2,00 & 0,25 & 0,33 & 1,00 \\
P3 & 1,00 & 0,50 & 1,00 & 0,50 & 2,00 & 0,50 & 1,00 & 0,50 \\
P4 & 0,33 & 3,00 & 2,00 & 1,00 & 3,00 & 0,33 & 0,33 & 3,00 \\
P5 & 0,50 & 0,50 & 0,50 & 0,33 & 1,00 & 0,25 & 0,50 & 0,50 \\
P6 & 2,00 & 4,00 & 2,00 & 3,00 & 4,00 & 1,00 & 2,00 & 4,00 \\
P7 & 5,00 & 4,00 & 3,00 & 2,00 & 3,00 & 0,50 & 5,00 & 4,00 \\
P8 & 1,00 & 3,00 & 1,00 & 3,00 & 2,00 & 0,50 & 1,00 & 3,00 \\
\hline
\end{tabular}

Tablo 7. Alternatiflerin Personel Sayıs1 Kriteri Açısından İkili Karşılaştırma Matrisi

\begin{tabular}{ccccccccc}
\hline Alternatifler & P1 & P2 & P3 & P4 & P5 & P6 & P7 & P8 \\
\hline P1 & 1,00 & 2,00 & 0,25 & 0,20 & 0,50 & 0,13 & 1,00 & 2,00 \\
P2 & 0,50 & 1,00 & 0,33 & 0,25 & 0,50 & 0,14 & 0,50 & 1,00 \\
P3 & 4,00 & 3,00 & 1,00 & 0,50 & 2,00 & 0,50 & 4,00 & 3,00 \\
P4 & 5,00 & 4,00 & 2,00 & 1,00 & 3,00 & 0,33 & 5,00 & 4,00 \\
P5 & 2,00 & 2,00 & 0,50 & 0,33 & 1,00 & 0,25 & 2,00 & 2,00 \\
P6 & 8,00 & 7,00 & 2,00 & 3,00 & 4,00 & 1,00 & 8,00 & 7,00 \\
P7 & 7,00 & 6,00 & 3,00 & 2,00 & 3,00 & 0,50 & 7,00 & 6,00 \\
P8 & 1,00 & 2,00 & 0,25 & 0,20 & 0,50 & 0,13 & 1,00 & 2,00
\end{tabular}


Tablo 8. Alternatiflerin Ekonomiye Katk1 Kriteri Açısından İkili Karşılaştırma Matrisi

\begin{tabular}{ccccccccc}
\hline Alternatifler & P1 & P2 & P3 & P4 & P5 & P6 & P7 & P8 \\
\hline P1 & 1,00 & 0,33 & 0,17 & 0,14 & 0,25 & 0,11 & 1,00 & 0,33 \\
P2 & 3,00 & 1,00 & 0,33 & 0,25 & 0,25 & 0,13 & 3,00 & 1,00 \\
P3 & 6,00 & 3,00 & 1,00 & 1,00 & 3,00 & 0,33 & 6,00 & 3,00 \\
P4 & 7,00 & 4,00 & 1,00 & 1,00 & 3,00 & 1,00 & 7,00 & 4,00 \\
P5 & 4,00 & 4,00 & 0,33 & 0,33 & 1,00 & 0,17 & 4,00 & 4,00 \\
P6 & 9,00 & 8,00 & 3,00 & 1,00 & 6,00 & 1,00 & 9,00 & 8,00 \\
P7 & 9,00 & 8,00 & 3,00 & 0,33 & 5,00 & 0,50 & 9,00 & 8,00 \\
P8 & 1,00 & 0,33 & 0,17 & 0,14 & 0,25 & 0,11 & 1,00 & 0,33 \\
\hline
\end{tabular}

Kriterlerin kriterler açısından ikili karşılaştırma matrisinden elde edilen normalize matris Tablo 9'da oluşturulmuştur.

Alternatiflerin proje bütçesi kriteri açısından ikili karşılaştırma matrisinden elde edilen normalize matris Tablo 10'da oluşturulmuştur.

Alternatiflerin proje süresi kriteri açısından ikili karşılaştırma matrisinden elde edilen normalize matris Tablo 11'de oluşturulmuştur.

Tablo 9. Kriterlerin Kriterler Açısından Normalize Matrisi

\begin{tabular}{cccccc} 
Kriterler & K1 & K2 & K3 & K4 & K5 \\
\hline K1 & 0,19 & 0,31 & 0,21 & 0,18 & 0,16 \\
K2 & 0,09 & 0,15 & 0,07 & 0,18 & 0,23 \\
K3 & 0,06 & 0,15 & 0,07 & 0,02 & 0,07 \\
K4 & 0,09 & 0,08 & 0,14 & 0,09 & 0,08 \\
K5 & 0,56 & 0,31 & 0,50 & 0,54 & 0,47
\end{tabular}

Alternatiflerin bağımlılık durumu kriteri açısından ikili karşılaştırma matrisinden elde edilen normalize matris Tablo 12'de oluşturulmuştur.

Alternatiflerin personel sayısı kriteri açısından ikili karşılaştırma matrisinden elde edilen normalize matris Tablo 13'de oluşturulmuştur.
Tablo 10. Alternatiflerin Proje Bütçesi Kriteri Açısından Normalize Matrisi

\begin{tabular}{cccccccccc}
\hline Alternatifler & P1 & P2 & P3 & P4 & P5 & P6 & P7 & P8 \\
\hline P1 & 0,02 & 0,07 & 0,02 & 0,03 & 0,01 & 0,03 & 0,02 & 0,02 \\
P2 & 0,01 & 0,03 & 0,03 & 0,05 & 0,01 & 0,04 & 0,02 & 0,10 \\
P3 & 0,21 & 0,16 & 0,15 & 0,24 & 0,19 & 0,14 & 0,08 & 0,19 \\
P4 & 0,21 & 0,16 & 0,15 & 0,24 & 0,19 & 0,28 & 0,32 & 0,24 \\
P5 & 0,07 & 0,10 & 0,03 & 0,05 & 0,04 & 0,04 & 0,03 & 0,02 \\
P6 & 0,21 & 0,23 & 0,30 & 0,24 & 0,26 & 0,28 & 0,32 & 0,24 \\
P7 & 0,21 & 0,23 & 0,30 & 0,12 & 0,19 & 0,14 & 0,16 & 0,15 \\
P8 & 0,07 & 0,02 & 0,04 & 0,05 & 0,11 & 0,06 & 0,05 & 0,05
\end{tabular}

Tablo 11. Alternatiflerin Proje Süresi Kriteri Açısından Normalize Matrisi

\begin{tabular}{ccccccccc} 
Alternatifler & P1 & P2 & P3 & P4 & P5 & P6 & P7 & P8 \\
\hline P1 & 0,02 & 0,02 & 0,01 & 0,04 & 0,01 & 0,03 & 0,02 & 0,01 \\
P2 & 0,05 & 0,03 & 0,03 & 0,05 & 0,02 & 0,04 & 0,02 & 0,03 \\
P3 & 0,17 & 0,13 & 0,10 & 0,10 & 0,11 & 0,10 & 0,05 & 0,17 \\
P4 & 0,17 & 0,20 & 0,30 & 0,30 & 0,19 & 0,30 & 0,55 & 0,17 \\
P5 & 0,07 & 0,07 & 0,03 & 0,06 & 0,04 & 0,04 & 0,02 & 0,03 \\
P6 & 0,22 & 0,26 & 0,30 & 0,30 & 0,30 & 0,30 & 0,22 & 0,33 \\
P7 & 0,17 & 0,23 & 0,20 & 0,06 & 0,26 & 0,15 & 0,11 & 0,22 \\
P8 & 0,12 & 0,07 & 0,03 & 0,10 & 0,08 & 0,05 & 0,03 & 0,06 \\
\hline
\end{tabular}

Alternatiflerin ekonomiye katkı kriteri açısından ikili karşılaştırma matrisinden elde edilen normalize matris Tablo 14'de oluşturulmuştur.

Aşama-7: Öncelik vektör matrisinin oluşturulması: Kriterlerin kriterler açısından, alternatiflerinde kriterler açısından ikili karşılaştırma matrislerinden elde edilen öncelik vektör matrisleri aşağıda tablolar halinde verilmiştir. Kriterlerin kriterler açısından ikili karşılaștırma matrisinden elde edilen öncelik vektör matrisi Tablo 15'de oluşturulmuştur. 
Tablo 12. Alternatiflerin Bağımlılık Durumu Kriteri Açısından Normalize Matrisi

\begin{tabular}{|c|c|c|c|c|c|c|c|c|}
\hline Alternatifler & P1 & P2 & P3 & P4 & P5 & P6 & P7 & P8 \\
\hline $\mathrm{P} 1$ & 0,09 & 0,18 & 0,08 & 0,29 & 0,11 & 0,14 & 0,04 & 0,10 \\
\hline $\mathrm{P} 2$ & 0,03 & 0,06 & 0,17 & 0,03 & 0,11 & 0,07 & 0,05 & 0,10 \\
\hline P3 & 0,09 & 0,03 & 0,08 & 0,05 & 0,11 & 0,14 & 0,07 & 0,10 \\
\hline P4 & 0,03 & 0,18 & 0,17 & 0,10 & 0,17 & 0,09 & 0,10 & 0,15 \\
\hline P5 & 0,05 & 0,03 & 0,04 & 0,03 & 0,06 & 0,07 & 0,07 & 0,10 \\
\hline P6 & 0,19 & 0,24 & 0,17 & 0,29 & 0,23 & 0,28 & 0,41 & 0,20 \\
\hline $\mathrm{P} 7$ & 0,47 & 0,24 & 0,25 & 0,19 & 0,17 & 0,14 & 0,21 & 0,20 \\
\hline P8 & 0,05 & 0,03 & 0,04 & 0,03 & 0,03 & 0,07 & 0,05 & 0,05 \\
\hline
\end{tabular}

Tablo 13. Alternatiflerin Personel Sayısı Kriteri Açısından Normalize Matrisi

\begin{tabular}{|c|c|c|c|c|c|c|c|c|}
\hline Alternatifler & P1 & P2 & P3 & P4 & P5 & P6 & P7 & P8 \\
\hline P1 & 0,04 & 0,08 & 0,03 & 0,03 & 0,03 & 0,04 & 0,03 & 0,06 \\
\hline $\mathrm{P} 2$ & 0,02 & 0,04 & 0,04 & 0,03 & 0,03 & 0,05 & 0,04 & 0,06 \\
\hline P3 & 0,14 & 0,12 & 0,10 & 0,07 & 0,14 & 0,16 & 0,07 & 0,11 \\
\hline $\mathrm{P} 4$ & 0,18 & 0,15 & 0,21 & 0,13 & 0,21 & 0,11 & 0,11 & 0,17 \\
\hline P5 & 0,07 & 0,08 & 0,05 & 0,04 & 0,07 & 0,08 & 0,07 & 0,11 \\
\hline P6 & 0,28 & 0,27 & 0,21 & 0,39 & 0,28 & 0,32 & 0,42 & 0,22 \\
\hline P7 & 0,25 & 0,23 & 0,31 & 0,26 & 0,21 & 0,16 & 0,21 & 0,22 \\
\hline P8 & 0,04 & 0,04 & 0,05 & 0,04 & 0,03 & 0,08 & 0,05 & 0,06 \\
\hline
\end{tabular}

Alternatiflerin kriterler açısından ikili karşılaştırma matrislerinden elde edilen öncelik vektör matrisleri Tablo 16'da oluşturulmuş̧ur.

Aşama-8: Sütun vektör matrisinin oluşturulması: Kriterlerin kriterler açısından, alternatiflerinde kriterler açısından ikili karşılaştırma matrislerinden elde edilen sütun vektör matrisleri aşağıda tablolar halinde verilmiştir. Kriterlerin kriterler açısından ikili karş1laştırma matrisinden elde edilen sütun vektör matrisi Tablo 17'de oluşturulmuştur.
Tablo 14. Alternatiflerin Ekonomiye Katk1 Kriteri Açısından Normalize Matrisi

\begin{tabular}{ccccccccc}
\hline Alternatifler & P1 & P2 & P3 & P4 & P5 & P6 & P7 & P8 \\
\hline P1 & 0,02 & 0,01 & 0,02 & 0,03 & 0,01 & 0,03 & 0,02 & 0,01 \\
P2 & 0,06 & 0,03 & 0,03 & 0,06 & 0,01 & 0,04 & 0,02 & 0,01 \\
P3 & 0,13 & 0,09 & 0,09 & 0,23 & 0,14 & 0,10 & 0,05 & 0,04 \\
P4 & 0,15 & 0,12 & 0,09 & 0,23 & 0,14 & 0,29 & 0,43 & 0,23 \\
P5 & 0,08 & 0,12 & 0,03 & 0,08 & 0,05 & 0,05 & 0,03 & 0,03 \\
P6 & 0,19 & 0,23 & 0,28 & 0,23 & 0,28 & 0,29 & 0,29 & 0,31 \\
P7 & 0,19 & 0,23 & 0,28 & 0,08 & 0,23 & 0,14 & 0,14 & 0,31 \\
P8 & 0,19 & 0,18 & 0,19 & 0,08 & 0,14 & 0,07 & 0,04 & 0,08 \\
\hline
\end{tabular}

Tablo 15. Kriterlerin Kriterler Açısından Öncelik Vektör Matrisi

\begin{tabular}{cc} 
Kriterler & Ağırlıklar \\
\hline K1 & 0,21 \\
K2 & 0,15 \\
K3 & 0,07 \\
K4 & 0,10 \\
K5 & 0,48
\end{tabular}

Tablo 16. Alternatiflerin Kriterler Açısından Öncelik Vektör Matrisleri

\begin{tabular}{ccccccc}
\hline Alternatifler/Kriterler & $\mathbf{K 1}$ & $\mathbf{K 2}$ & $\mathbf{K 3}$ & $\mathbf{K 4}$ & $\mathbf{K 5}$ \\
\hline P1 & 0,03 & 0,02 & 0,13 & 0,04 & 0,02 \\
P2 & 0,04 & 0,03 & 0,08 & 0,04 & 0,03 \\
P3 & 0,17 & 0,12 & 0,09 & 0,11 & 0,11 \\
P4 & 0,22 & 0,27 & 0,12 & 0,16 & 0,21 \\
P5 & 0,05 & 0,04 & 0,06 & 0,07 & 0,06 \\
P6 & 0,26 & 0,28 & 0,25 & 0,30 & 0,26 \\
P7 & 0,19 & 0,18 & 0,23 & 0,23 & 0,20 \\
P8 & 0,06 & 0,07 & 0,04 & 0,05 & 0,12 \\
\hline
\end{tabular}


Tablo 17. Kriterlerin Kriterler Açısından Sütun Vektör Matrisi

\begin{tabular}{cc} 
Kriterler & Sütun Vektörleri \\
\hline K1 & 1,08 \\
K2 & 0,76 \\
K3 & 0,38 \\
K4 & 0,50 \\
K5 & 2,49 \\
\hline
\end{tabular}

Alternatiflerin kriterler açısından ikili karşılaştırma matrislerinden elde edilen sütun vektör matrisleri Tablo 18'de oluşturulmuştur.

Aşama-9: Temel değerin elde edilmesi: Kriterlerin kriterler açısından, alternatiflerinde kriterler açısından ikili karşılaştırma matrislerinden elde edilen temel değerler aşağıda tablolar halinde verilmiştir. Kriterlerin kriterler açısından ikili karş1laştırma matrisinden elde edilen temel değerler Tablo 19'da oluşturulmuştur.

Alternatiflerin kriterler açısından ikili karşılaştırma matrislerinden elde edilen temel değerler Tablo 20'de oluşturulmuştur.

Tablo 18. Alternatiflerin Kriterler Açısından Sütun Vektör Matrisleri

\begin{tabular}{cccccc} 
Alternatifler/Kriterler & $\mathbf{K 1}$ & $\mathbf{K 2}$ & $\mathbf{K 3}$ & $\mathbf{K 4}$ & $\mathbf{K 5}$ \\
\hline P1 & 0,23 & 0,18 & 1,19 & 0,33 & 0,16 \\
P2 & 0,32 & 0,26 & 0,65 & 0,30 & 0,27 \\
P3 & 1,48 & 0,99 & 0,72 & 0,93 & 0,90 \\
P4 & 1,95 & 2,52 & 1,07 & 1,31 & 1,96 \\
P5 & 0,41 & 0,36 & 0,47 & 0,59 & 0,49 \\
P6 & 2,28 & 2,43 & 2,23 & 2,53 & 2,42 \\
P7 & 1,65 & 1,54 & 2,17 & 1,95 & 1,90 \\
P8 & 0,49 & 0,54 & 0,38 & 0,40 & 1,04
\end{tabular}

Tablo 19. Kriterlerin Kriterler Açısından Temel Değerleri

\begin{tabular}{cc}
\hline Kriterler & Temel Değerler \\
\hline K1 & 5,15 \\
K2 & 5,16 \\
K3 & 5,07 \\
K4 & 5,22 \\
K5 & 5,25 \\
\hline
\end{tabular}

Aşama-10: Lamda $(\lambda)$ değerinin elde edilmesi: Kriterlerin kriterler açısından, alternatiflerinde kriterler açısından ikili karşılaştırma matrislerinden elde edilen $\lambda$ değerleri aşağıda verilmiştir.

Kriterlerin kriterler açısından ikili karşılaştırma matrisinden elde edilen $\lambda$ değeri 5,169 olarak bulunmuştur. Alternatiflerin kriterler açısından ikili karşılaştırma matrislerinden elde edilen $\lambda$ değerleri Tablo 21'de oluşturulmuştur.

Tablo 20. Alternatiflerin Kriterler Açısından Temel Değerleri

\begin{tabular}{cccccc}
\hline $\begin{array}{c}\text { Alternatifler } \\
\text { Kriterler }\end{array}$ & K1 & K2 & K3 & K4 & K5 \\
\hline P1 & 8,67 & 8,30 & 9,17 & 8,12 & 8,48 \\
P2 & 8,65 & 8,24 & 8,34 & 8,15 & 8,27 \\
P3 & 8,75 & 8,51 & 8,48 & 8,24 & 8,48 \\
P4 & 8,73 & 9,36 & 8,63 & 8,36 & 9,40 \\
P5 & 8,77 & 8,17 & 8,46 & 8,17 & 8,55 \\
P6 & 8,81 & 8,77 & 8,91 & 8,44 & 9,32 \\
P7 & 8,92 & 8,81 & 9,27 & 8,43 & 9,51 \\
P8 & 8,93 & 8,23 & 8,69 & 8,23 & 8,83 \\
\hline
\end{tabular}


Tablo 21. Alternatiflerin Kriterler Açısından $\lambda$ Değerleri

\begin{tabular}{cc}
\hline Kriterler & $\lambda$ Değerleri \\
\hline K1 & 8,78 \\
K2 & 8,55 \\
K3 & 8,74 \\
K4 & 8,27 \\
K5 & 8,85 \\
\hline
\end{tabular}

Tablo 22. Alternatiflerin Kriterler Açısından Tutarlılık İndeksleri

\begin{tabular}{cc}
\hline Kriterler & Tutarlılı İndeksleri \\
\hline K1 & 0,11 \\
K2 & 0,08 \\
K3 & 0,11 \\
K4 & 0,04 \\
K5 & 0,12 \\
\hline
\end{tabular}

Aşama-11: Tutarlılık indeksinin hesaplanması: Kriterlerin kriterler açısından, alternatiflerinde kriterler açısından ikili karşılaştırma matrislerinden elde edilen tutarlılık indeksleri aşağıda verilmiştir. Kriterlerin kriterler açısından ikili karşılaştırma matrisinden elde edilen tutarlılık indeksi 0,042 olarak bulunmuştur. Alternatiflerin kriterler açısından ikili karşılaştırma matrislerinden elde edilen tutarlilik indeksleri Tablo 22'de oluşturulmuştur.

Aşama-12: Tutarlılık oranının hesaplanması: Kriterlerin kriterler açısından, alternatiflerinde kriterler açısından ikili karşılaştırma matrislerinden elde edilen tutarlılık oranları aşağıda verilmiştir. Kriterlerin kriterler açısından ikili karşılaştırma matrisinden elde edilen tutarlılık oranı 0,038 olarak bulunmuştur. Alternatiflerin kriterler açısından ikili karş1laştırma matrislerinden elde edilen tutarlılık oranları Tablo 23'de oluşturulmuştur.
Tablo 23. Alternatiflerin Kriterler Açısından Tutarlılık Oranları

\begin{tabular}{cc}
\hline Kriterler & $\begin{array}{r}\text { Tutarlılı } \\
\text { Oranları }\end{array}$ \\
\hline K1 & 0,08 \\
K2 & 0,06 \\
K3 & 0,08 \\
K4 & 0,03 \\
K5 & 0,09 \\
\hline
\end{tabular}

Aşama-13: Sonucun bulunması: Alternatiflerin özvektörleri (ağırlıkları) ile kriterlerin özvektörlerinin çarpılması ile elde edilen sonuçlardan en yüksek değer bizi sonuca götürmektedir. Hesaplama sonuçlarına ilişkin ağırlıklar Tablo 24'de belirtilmiştir. Ayrıca sonuç grafiği de Şekil 2'de verilmiştir. Tabloya göre en yüksek değere sahip 6. projenin seçilmesi uygun gözükmektedir.

Tablo 24. Ağırlıklar Tablosu

\begin{tabular}{cc} 
Alternatifler & Ağırlıklar \\
\hline P1 & 0,03 \\
P2 & 0,04 \\
P3 & 0,12 \\
P4 & 0,21 \\
P5 & 0,05 \\
P6 & 0,27 \\
P7 & 0,20 \\
P8 & 0,09 \\
\hline
\end{tabular}

AHS yönteminde yapılan hesaplamalar sonucuna göre en yüksek ağırlık değerine sahip olan P6 (6. Proje), diğer alternatiflere göre ilk tercih edilmesi gereken proje gözükmektedir. Hesaplanan ağırlık değerlerine göre ilk tercih sırası P6'e ait olmakla birlikte, bu projeyi sırasıly P4, P7, P3, P8, P5, P2, P1 izlemektedir. Yatırım uzmanlarından alınan bilgiler doğrultusunda uygulama sonucunda 
en uygun yatırım projesinin P6 (6. proje) çıkması, işletmenin de bu yatırım projesinin üzerinde durduğunu, bu projeye önem verildiğini ve bu proje için yatırım yapılacağını belirtmişlerdir.

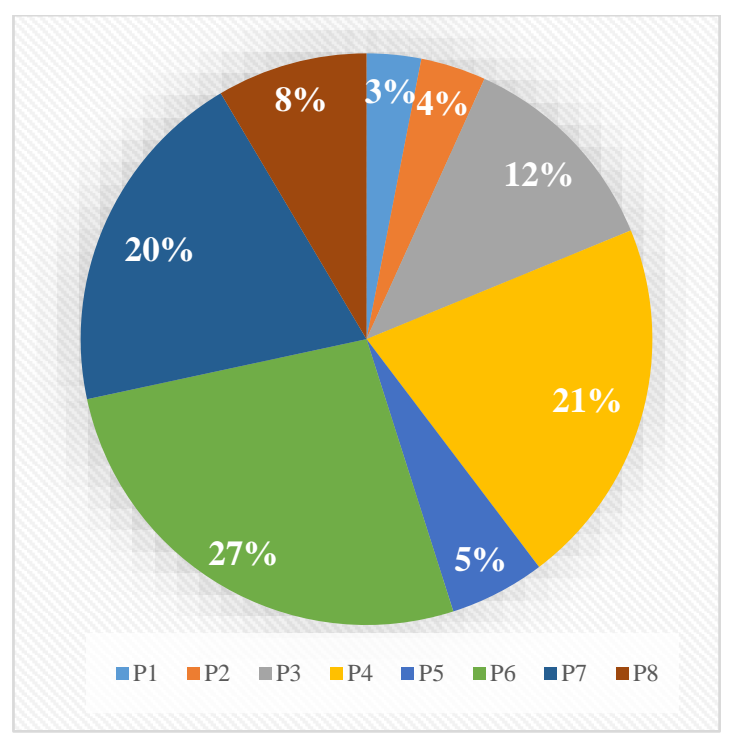

Şekil 2. Sonuç Grafiğgi

\section{VIKOR Yöntemi}

Öncelikle kriterlerin belirlenmesi gerekmektedir. AHS yönteminde kullanılan kriterler VIKOR yönteminde de kullanılmıștır. Kriterlere ilişkin açıklamalar aşağıda yapılmıştır. Çözüm aşamasında kullanılacak kriterlere ait veriler Tablo 25'de verilmiştir.

Proje Bütçesi (K1) : $\quad$ Her bir projenin gerçekleşmesi için öngörülen para değeridir.

Proje Süresi (K2) : Projenin tamamlanabilmesi için gereken ay bazında süredir.

Bağımlılık Durumu (K3) : Bağımlılık durumunda üç olay söz konusudur. 1-Projenin şirket içinde yapılacağını, 2-Projenin dışarıdan hizmet alımı ile yapılacağını, 3-Projenin şirket içi veya dışarıdan hizmet alımı ile yapılacağını gösterir.

Personel Sayısı (K4) : Projede çalışması gereken kaç adet personele ihtiyaç olduğudur.

Ekonomiye Katk1 (K5) : Projenin ülke ekonomisine katkısıdır. Ekonomik katkı skalası şu şekildedir: 5-Çok yüksek, 4-Yüksek, 3-Orta, 2-Az, 1-Yok

Tablo 25'te yer alan P1,...P8, AHS yönteminde kullanılan alternatiflerdir.
Tablo 25. Uygulamada Kullanılan Veriler

\begin{tabular}{crrrrr}
\hline Kriterler & K1 & K2 & K3 & K4 & K5 \\
\hline P1 & 471278 & 25 & 2 & 137 & 2 \\
P2 & 1230270 & 19 & 3 & 318 & 4 \\
P3 & 123157842 & 70 & 3 & 778 & 3 \\
P4 & 82926965 & 38 & 1 & 464 & 4 \\
P5 & 792182 & 22 & 3 & 96 & 3 \\
P6 & 8233158 & 33 & 3 & 572 & 4 \\
P7 & 1610662 & 8 & 2 & 87 & 4 \\
P8 & 3636784 & 66 & 2 & 504 & 4 \\
\hline
\end{tabular}

VIKOR yöntemi ile problemin çözümü aşamalar halinde aşağıda verilmiştir.

Aşama-1: Her kriter için en iyi $\left(f_{i}^{+}\right)$ve en kötü $\left(f_{i}^{-}\right)$değerleri belirlenir. Bu değerler Tablo 26'da belirtilmiştir.

Tablo 26. En iyi $\left(f_{i}^{+}\right)$ve en kötü $\left(f_{i}^{-}\right)$değerleri

\begin{tabular}{ccc}
\hline Kriterler & $f_{i}^{+}$ & $f_{i}^{-}$ \\
\hline K1 & 471278 & 123157842 \\
K2 & 8 & 70 \\
K3 & 3 & 1 \\
K4 & 87 & 778 \\
K5 & 4 & 2
\end{tabular}

Aşama-2: $S_{j}$ ve $R_{j}$ değerleri $j=1,2, \ldots, m$ için hesaplanır. Hesaplamalardaki $w_{i}$ değerleri AHS'nde hesaplanan kriterlerin ağırlı (öz vektör) değerleridir. $S_{j}$ ve $R_{j}$ değerleri Tablo 27'de belirtilmiştir.

Aşama-3: $Q_{j}$ değerleri tüm $j=1,2, \ldots, m$ için belirlenir. Farklı "v" değerleri için hesaplanan $\mathrm{Q}_{\mathrm{j}}$ değerleri Tablo 28'de belirtilmiștir.

Aşama-4: $S_{j}, R_{j}$ ve $Q_{j}$ değerleri küçükten büyüğe doğru sıralanarak alternatifler arasındaki sıralama belirlenir. $\mathrm{Bu}$ siralama listesi Tablo 29'da 
belirtilmiştir. $Q_{j} \quad$ sıralaması $\mathrm{v}=0,5$ değerine sonuçlarına göre sıralama yapılmıştır.

Tablo 27. $S_{j}$ ve $R_{j}$ Değerleri

\begin{tabular}{cccccccc}
\hline $\begin{array}{c}\text { Alternatifler } \\
\text { Kriterler }\end{array}$ & $\mathbf{K 1}$ & $\mathbf{K 2}$ & $\mathbf{K 3}$ & $\mathbf{K 4}$ & $\mathbf{K 5}$ & $\mathbf{S}_{\mathbf{j}}$ & $\mathbf{R}_{\mathbf{j}}$ \\
\hline P1 & 0,00 & 0,04 & 0,04 & 0,01 & 0,48 & 0,56 & 0,48 \\
P2 & 0,00 & 0,03 & 0,00 & 0,03 & 0,00 & 0,06 & 0,03 \\
P3 & 0,21 & 0,15 & 0,00 & 0,10 & 0,24 & 0,69 & 0,24 \\
P4 & 0,14 & 0,07 & 0,07 & 0,05 & 0,00 & 0,34 & 0,14 \\
P5 & 0,00 & 0,03 & 0,00 & 0,00 & 0,24 & 0,27 & 0,24 \\
P6 & 0,01 & 0,06 & 0,00 & 0,07 & 0,00 & 0,14 & 0,07 \\
P7 & 0,00 & 0,00 & 0,04 & 0,00 & 0,00 & 0,04 & 0,04 \\
P8 & 0,01 & 0,14 & 0,04 & 0,06 & 0,00 & 0,24 & 0,14
\end{tabular}

Tablo 28. $Q_{j}$ Değerleri

\begin{tabular}{|c|c|c|c|c|c|c|c|c|}
\hline $\begin{array}{c}\text { Maksimum } \\
\text { Grup } \\
\text { Faydası / } \\
\text { Alternatif }\end{array}$ & P1 & $\mathbf{P 2}$ & P3 & P4 & P5 & P6 & P7 & P8 \\
\hline Q1 (v=0) & 1,00 & 0,00 & 0,46 & 0,24 & 0,46 & 0,08 & 0,01 & 0,24 \\
\hline $\mathrm{Q} 2(\mathrm{v}=0,1)$ & 0,98 & 0,00 & 0,52 & 0,27 & 0,45 & 0,09 & 0,01 & 0,24 \\
\hline $\mathrm{Q} 3(\mathrm{v}=0,2)$ & 0,96 & 0,01 & 0,57 & 0,29 & 0,44 & 0,10 & 0,01 & 0,25 \\
\hline $\mathrm{Q} 4(\mathrm{v}=0,3)$ & 0,94 & 0,01 & 0,63 & 0,31 & 0,43 & 0,10 & 0,01 & 0,26 \\
\hline Q5 $(v=0,4)$ & 0,92 & 0,01 & 0,68 & 0,33 & 0,42 & 0,11 & 0,01 & 0,26 \\
\hline Q6 $(v=0,5)$ & 0,90 & 0,02 & 0,73 & 0,35 & 0,41 & 0,12 & 0,01 & 0,27 \\
\hline Q7 (v=0,6) & 0,88 & 0,02 & 0,79 & 0,37 & 0,40 & 0,13 & 0,01 & 0,28 \\
\hline Q8 (v=0,7) & 0,86 & 0,02 & 0,84 & 0,40 & 0,39 & 0,13 & 0,00 & 0,29 \\
\hline Q9 $(v=0,8)$ & 0,84 & 0,03 & 0,89 & 0,42 & 0,38 & 0,14 & 0,00 & 0,29 \\
\hline $\mathrm{Q} 10(\mathrm{v}=0,9)$ & 0,82 & 0,03 & 0,95 & 0,44 & 0,37 & 0,15 & 0,00 & 0,30 \\
\hline $\mathrm{Q} 11(\mathrm{v}=1)$ & 0,80 & 0,03 & 1,00 & 0,46 & 0,36 & 0,16 & 0,00 & 0,31 \\
\hline
\end{tabular}

Aşama-5: Her iki koşulun sağlanıp sağlanmadığının kontrolünün yapılmas1;

Hesaplama sonucuna göre Q değerleri içerisinde en düşük değeri barındıran P7 ( 7. Proje), öbür alternatiflere kiyasla kabul edilebilir bir avantaja sahip gözükmektedir.

Tablo 29. Siralama Listesi

\begin{tabular}{cccccc}
\hline Alternatif & $\mathbf{S j}$ & Alternatif & $\mathbf{R j}$ & Alternatif & $\mathbf{Q j}$ \\
\hline P7 & 0,04 & P2 & 0,032 & P7 & 0,01 \\
P2 & 0,06 & P7 & 0,037 & P2 & 0,02 \\
P6 & 0,14 & P6 & 0,067 & P6 & 0,12 \\
P8 & 0,24 & P8 & 0,137 & P8 & 0,27 \\
P5 & 0,27 & P4 & 0,140 & P4 & 0,35 \\
P4 & 0,34 & P5 & 0,237 & P5 & 0,41 \\
P1 & 0,56 & P3 & 0,237 & P3 & 0,73 \\
P3 & 0,69 & P1 & 0,475 & P1 & 0,90 \\
\hline
\end{tabular}

P7 alternatifinin en iyi olarak kabul edilebilmesi için yöntemin kapsamında olan iki koşulun sağlanması önemle gerekmektedir.

Koşul-1: Q(t2) - Q (t1) $\geq$ DQ eşitsizliği sağlanmalıdır.

$$
\mathrm{DQ}=1 /(8-1)=0,143
$$

Elde ettiğimizde değerleri yerine yazarsak; $0,016-0,006 \geq 0,010$

$0,010 \geq 0,143$ bulunan sonuç Koşul-1'in sağlanmadığını göstermektedir.

Koşul-2: Elde edilen çözümün kabul edilebilir istikrarlı olması için en iyi alternatif olan $t^{\prime}$ alternatifi, $\mathrm{Sj}$ ve $\mathrm{Rj}$ değerlerinin değerlerinden en az birinde en iyi puanı elde etmelidir.

Tablo 29'daki $S_{j}$ ve $R_{j}$ siralamalardan $S_{j}$ 'de P7'ni ilk sırada yer aldığ görülmekte olup Koşul-2 de sağlanmıştır.

Hesaplamalar sonucuna göre P6 maksimum Q değerine sahip olan yatırım projesidir. P7 ise minimum $\mathrm{Q}$ değerine sahip yatırm projesidir. Uzlaşık çözüm kümesi içerisinde $Q$ değerlerine göre sıralama yapılırsa en iyi yatırım projesi, minimum $\mathrm{Q}$ değerlerine sahip olan $\mathrm{P} 7 \mathrm{ve} \mathrm{P} 2$ yatırım projelerinden birisidir. $\mathrm{Bu}$ yatırım projelerini sirasıyla P6, P8, P4, P5, P3, P1 yatırım projeleri takip etmektedir. 


\section{Hedef Programlama}

Şirket, mevcut yatırım yapılabilir projeler üzerinde, çeşitli analizler ve değerlendirmeler sonucunda bir takım elemeler yaparak, şirketin kârına olan yatırım projelerine yatırım yapma düşüncesindedir. 8 ana proje kapsamında, 37 alt projeden oluşan, yatırım yapılması düşünülen projelerin seçimi üzerinde hedef programlama ile matematiksel çözümleme yapılacaktır. Ana proje ve alt proje bilgileri Tablo 31'dedir. Bilgiler yatırım projeleri ile ilgili şirketinin bütününde çalışma yapan Yatırım Planlama Bölümü’nden sağlanmıştır.

Modelin çözümü içi belirlenen hedeflere ilişkin detay bilgiler aşağıda belirtilmiştir.

Yatırım projeleri için ayrılan 160 milyon TL bütçe, Mali İşler Bölümü ve Üretim Bölümü'nde çalışmakta olan yatırım uzmanları tarafından belirlenmiştir. Yatırım projeleri için gereken değerin belirlenen bütçe değerini aşmaması gerektiği belirtilmişsir.

Projeler kapsamında çalışabilecek personel sayıs1 2750 olarak belirlenmiştir. $\mathrm{Bu}$ sayının belirlenmesinde Üretim Bölümü'ndeki saha amirleri, üretim uzmanlarından ve İnsan Kaynakları Bölümü'nden destek alınmıştır. Personel sayısı 2750'yi aşmamalıdır.

AHS yönteminde hesaplama işlemi yapılmış olan ağırlık değerleri bulunmuş ana projelerin kapsamındaki en fazla alt proje seçilmesi istenmektedir. Ana proje kapsamındaki tüm alt projelerin eşit ağırlıkta olduğu varsayılmıştır. Bundan dolayı AHS yönteminde bulunmuş olan değer ana proje kapsamındaki alt projelerin sayısına bölünerek her bir alt projesinin ağıllık değeri hesabı yapılmıştır.

VIKOR yönteminde hesaplama işlemi yapılarak sıralaması bulunmuş olan ana projelerin kapsamindaki en fazla alt proje seçilmesi istenmektedir.

Ana projeler içinden kesinlikle seçilmesi gereken alt projelere ilişkin açıklamalar aşağıda belirtilmiştir. Kısıtların belirlenmesinde ülke savunması ve ülke ekonomisinde büyük katkı sağladığ 1 için şirket üst yönetimi tarafından onay almış kısıtlardır.
3. ana projenin 3., 4., 5. ve 8. alt projeleri kesinlikle seçilmelidir. Özellikle seçilmesi istenilen projelerin özelliği şudur: Ülke savunmasında kullanılan helikopterlerin satın alımlarındaki dışa bağımlığ 1 azaltmak ve milli helikopterimizin yapılması amaçlanmaktadır.

4. ana projenin 2., 3., 4. ve 5. alt projeleri kesinlikle seçilmelidir. Özellikle seçilmesi istenilen projelerin özelliği şudur: Ülke savunmasında kullanılan insansız hava aracı (IHA) satın alımlarındaki dışa bağımlığı azaltmak ve ülkemize tümüyle ait İHA'ların yapılması amaçlanmaktadır.

6. ana projenin 1., 2., 3. ve 4. alt projesi kesinlikle seçilmelidir. Özellikle seçilmesi istenilen projelerin özelliği şudur: Ülke savunmasında kullanılan savaş uçağı satın alımlarındaki dışa bağımlığı azaltmak ve milli savaş uçağımızın yapılması amaçlanmaktadır.

8. ana projenin 7. alt projesi yatırım yapılırsa 4 . ve 6. alt projelere de yatırım yapılmalıdır. Şayet 7 . alt projeye yatırım yapılmazsa 4 . ve 6 . alt projeye de yatırım yapılmamalıdır.

2., 5. ve 8 . ana projelerin içeriğindeki alt projelerde yatırım yapılması düşünülen araç yatırımlarından en fazla biri seçilmelidir.

3. ana projenin 6. alt projesindeki yazılım yatırım 1 yap1lırsa, 8. ana projenin 3. alt projesindeki yazılım yatırımına gerek bulunmamaktadır.

Kurulacak olan modeller kapsamında 14 farklı senaryo üzerinde çalışma yapılmıştır. Bu senaryolar modelin yapısından dolayı belirlenmiştir. Modellerin kurulum kapsamında eşit ağırlıklı ve öncelikli olan hedef programlama kullanılmıştır.

Örnek olarak Senaryo-1'in açıklaması aşağıda yapılmıştır.

Senaryo-1: Bütçe hedefi, personel sayısı hedefi ve AHS ağırlık hedefi kullanılarak kurulmuş olan hedef programlama matematiksel modelidir.

Diğer senaryolardaki detay bilgiler Tablo 30'da belirtilmiştir.

Parametreler

i: Ana proje

$$
\mathrm{i}=1,2, \ldots, 8
$$

$\mathrm{j}$ : Alt proje 
$\mathrm{b}_{\mathrm{ij}}$ : i. ana projenin $\mathrm{j}$. alt projesinin bütçesi

$\mathrm{p}_{\mathrm{ij}}$ : i. ana projenin $\mathrm{j}$. alt projesinin personel sayısı

Karar değişkenleri

$x_{i j}=\left\{\begin{array}{lr}1, i . \text { ana projenin } j . \text { alt projesi seçilirse } \\ 0, \quad \text { diğer durumlarda }\end{array}\right.$

$d_{i}^{+}=$Hedeflere ait kısıtlardaki pozitif yönde sapma değişkenleri

$d_{i}^{-}=$Hedeflere ait kısıtlardaki negatif yönde sapma değişkenleri

$$
x_{i j} \geq 0 \quad \forall{ }_{i}, \forall_{j}
$$

Hedefler İçin Oluşturulan Kısıtlar

1 - Tüm projelere ayrılan bütçe miktarının yer aldığ hedef kisitıdir.

$\sum_{i=1}^{8} \sum_{j=1}^{9} b_{i j} x_{i j}+d_{1}^{-}-d_{1}^{+}=160000000$

2- Tüm projelere ayrilan personel sayısının yer aldığ

$\sum_{i=1}^{8} \sum_{j=1}^{9} p_{i j} x_{i j}+d_{2}^{-}-d_{2}^{+}=2750$

3- AHS yönteminde bulunan ağırlık değerlerine göre seçilmesi istenilen alt projeleri gösteren hedef kısitıdır.

$\sum_{j=1}^{4} 0,01 x_{1 j}+\sum_{j=1}^{3} 0,01 x_{2 j}+\sum_{j=1}^{9} 0,01 x_{3 j}+$ $\sum_{j=1}^{5} 0,04 x_{4 j}+\sum_{j=1}^{3} 0,02 x_{5 j}+\sum_{j=1}^{4} 0,07 x_{6 j}+$ $\sum_{j=1}^{1} 0,20 x_{7 j} \sum_{j=1}^{8} 0,01 x_{8 j}+d_{3}^{-}-d_{3}^{+}=1$

4- VIKOR yönteminde bulunan siralama değerlerine göre seçilmesi istenilen alt projeleri gösteren hedef kısıtıdır.

$\sum_{j=1}^{4} 0,90 x_{1 j}+\sum_{j=1}^{3} 0,02 x_{2 j}+\sum_{j=1}^{9} 0,73 x_{3 j}+$ $\sum_{j=1}^{5} 0,35 x_{4 j}+\sum_{j=1}^{3} 0,41 x_{5 j}+\sum_{j=1}^{4} 0,12 x_{6 j}+$ $\sum_{j=1}^{1} 0,01 x_{7 j} \sum_{j=1}^{8} 0,27 x_{8 j}+d_{4}^{-}-d_{4}^{+}=0$

Genel Kisitlar

1- Kesinlikle seçilmesi istenilen alt projeler için oluşturulmuş genel kısıttır.

$$
\begin{aligned}
& X_{33}=1 \\
& X_{34}=1 \\
& X_{35}=1 \\
& X_{38}=1 \\
& X_{42}=1
\end{aligned}
$$

\begin{tabular}{|c|c|c|c|c|}
\hline Senaryo & Tür & Hedef-1 & Hedef-2 & Hedef-3 \\
\hline 1 & $\begin{array}{l}\text { HP-Eşit } \\
\text { Önem }\end{array}$ & Bütçe & $\begin{array}{l}\text { Personel } \\
\text { Sayısı }\end{array}$ & $\begin{array}{c}\text { AHS } \\
\text { Ağırlıkları }\end{array}$ \\
\hline 2 & $\begin{array}{l}\text { HP-Eşit } \\
\text { Önem }\end{array}$ & Bütçe & $\begin{array}{l}\text { Personel } \\
\text { Sayısı }\end{array}$ & $\begin{array}{c}\text { VIKOR } \\
\text { Ağırlıkları }\end{array}$ \\
\hline 3 & $\begin{array}{c}\text { HP- } \\
\text { Öncelikli }\end{array}$ & Bütçe & $\begin{array}{c}\text { Personel } \\
\text { Sayısı }\end{array}$ & $\begin{array}{c}\text { AHS } \\
\text { Ağırlıkları }\end{array}$ \\
\hline 4 & $\begin{array}{c}\text { HP- } \\
\text { Öncelikli }\end{array}$ & Bütçe & $\begin{array}{c}\text { AHS } \\
\text { Ağırlıkları }\end{array}$ & $\begin{array}{c}\text { Personel } \\
\text { Sayis1 }\end{array}$ \\
\hline 5 & $\begin{array}{c}\text { HP- } \\
\text { Öncelikli }\end{array}$ & $\begin{array}{l}\text { Personel } \\
\text { Say1sı }\end{array}$ & Bütçe & $\begin{array}{c}\text { AHS } \\
\text { Ağırlıkları }\end{array}$ \\
\hline 6 & $\begin{array}{c}\text { HP- } \\
\text { Öncelikli }\end{array}$ & $\begin{array}{l}\text { Personel } \\
\text { Say1s1 }\end{array}$ & $\begin{array}{c}\text { AHS } \\
\text { Ağırlıkları }\end{array}$ & Bütçe \\
\hline 7 & $\begin{array}{c}\text { HP- } \\
\text { Öncelikli }\end{array}$ & $\begin{array}{c}\text { AHS } \\
\text { Ağırlıkları }\end{array}$ & Bütçe & $\begin{array}{c}\text { Personel } \\
\text { Say1s1 }\end{array}$ \\
\hline 8 & $\begin{array}{c}\text { HP- } \\
\text { Öncelikli }\end{array}$ & $\begin{array}{c}\text { AHS } \\
\text { Ağırlıkları }\end{array}$ & $\begin{array}{c}\text { Personel } \\
\text { Sayısı }\end{array}$ & Bütçe \\
\hline 9 & $\begin{array}{c}\text { HP- } \\
\text { Öncelikli }\end{array}$ & Bütçe & $\begin{array}{c}\text { Personel } \\
\text { Sayısı }\end{array}$ & $\begin{array}{c}\text { VIKOR } \\
\text { Ağırlıkları }\end{array}$ \\
\hline 10 & $\begin{array}{c}\text { HP- } \\
\text { Öncelikli }\end{array}$ & Bütçe & $\begin{array}{c}\text { VIKOR } \\
\text { Ağırlıkları }\end{array}$ & $\begin{array}{c}\text { Personel } \\
\text { Say1s1 }\end{array}$ \\
\hline 11 & $\begin{array}{c}\text { HP- } \\
\text { Öncelikli }\end{array}$ & $\begin{array}{l}\text { Personel } \\
\text { Sayıs1 }\end{array}$ & Bütçe & $\begin{array}{c}\text { VIKOR } \\
\text { Ağırlıkları }\end{array}$ \\
\hline 12 & $\begin{array}{c}\text { HP- } \\
\text { Öncelikli }\end{array}$ & $\begin{array}{l}\text { Personel } \\
\text { Say1s1 }\end{array}$ & $\begin{array}{c}\text { VIKOR } \\
\text { Ağırlıkları }\end{array}$ & Bütçe \\
\hline 13 & $\begin{array}{c}\text { HP- } \\
\text { Öncelikli }\end{array}$ & $\begin{array}{c}\text { VIKOR } \\
\text { Ağırlıkları }\end{array}$ & Bütçe & $\begin{array}{c}\text { Personel } \\
\text { Sayıs1 }\end{array}$ \\
\hline 14 & $\begin{array}{c}\text { HP- } \\
\text { Öncelikli }\end{array}$ & $\begin{array}{c}\text { VIKOR } \\
\text { Ağırlıkları }\end{array}$ & $\begin{array}{c}\text { Personel } \\
\text { Sayis1 }\end{array}$ & Bütçe \\
\hline
\end{tabular}

$$
\begin{aligned}
& X_{43}=1 \\
& X_{43}=1 \\
& X_{44}=1 \\
& X_{45}=1 \\
& X_{61}=1 \\
& X_{62}=1 \\
& X_{63}=1 \\
& X_{64}=1
\end{aligned}
$$

Tablo 30. Senaryo Detay Bilgileri 
2- 8. ana projenin 7. alt projesine yatırım yapilırsa 4. ve 6. alt projelere de yatırım yapılmasinı kapsayan genel kısıttır. Aksi durumu da kapsayan k1sittır.

$2 X_{87}-X_{84}-X_{86} \leq 0$

3-2., 5. ve 8. ana projeler içeriğindeki alt projelerde yatırım yapılması düşünülen araç yatırımlarından en fazla birinin seçilmesi ile alakalı genel kısıttır.

$X_{22}+X_{52}+X_{88} \leq 1$

4- 3. ana projenin 6. alt projesindeki yazılım yatırımı yapılırsa, 8 . ana projenin 3. alt projesindeki yazılım yatırımına gerek bulunmaması ile alakalı genel kisittır.

$X_{36}+X_{83} \leq 1$

Senaryolar İçin Oluşturulan Amaç Fonksiyonları

Senaryo - 1

$\operatorname{Min~Z}=d_{1}^{+}+d_{2}^{+}+d_{3}^{-}+d_{3}^{+}$

Senaryo - 2

$\operatorname{Min~Z}=d_{1}^{+}+d_{2}^{+}+d_{4}^{-}+d_{4}^{+}$

Senaryo - 3

$\operatorname{Min~Z}=\mathrm{P} 1\left(d_{1}^{+}\right)+\mathrm{P} 2\left(d_{2}^{+}\right)+\mathrm{P} 3\left(d_{3}^{-}+d_{3}^{+}\right)$

Senaryo - 4

$\operatorname{Min} \mathrm{Z}=\mathrm{P} 1\left(d_{1}^{+}\right)+\mathrm{P} 2\left(d_{3}^{-}+d_{3}^{+}\right)+\mathrm{P} 3\left(d_{2}^{+}\right)$

Senaryo - 5

$\operatorname{Min} \mathrm{Z}=\mathrm{P} 1\left(d_{2}^{+}\right)+\mathrm{P} 2\left(d_{1}^{+}\right)+\mathrm{P} 3\left(d_{3}^{-}+d_{3}^{+}\right)$

Senaryo - 6

$\operatorname{Min} \mathrm{Z}=\mathrm{P} 1\left(d_{2}^{+}\right)+\mathrm{P} 2\left(d_{3}^{-}+d_{3}^{+}\right)+\mathrm{P} 3\left(d_{1}^{+}\right)$

Senaryo - 7

$\operatorname{Min} \mathrm{Z}=\mathrm{P} 1\left(d_{3}^{-}+d_{3}^{+}\right)+\mathrm{P} 2\left(d_{1}^{+}\right)+\mathrm{P} 3\left(d_{2}^{+}\right)$

Senaryo - 8

$\operatorname{Min} \mathrm{Z}=\mathrm{P} 1\left(d_{3}^{-}+d_{3}^{+}\right)+\mathrm{P} 2\left(d_{2}^{+}\right)+\mathrm{P} 3\left(d_{1}^{+}\right)$

Senaryo - 9

$\operatorname{Min} \mathrm{Z}=\mathrm{P} 1\left(d_{1}^{+}\right)+\mathrm{P} 2\left(d_{2}^{+}\right)+\mathrm{P} 3\left(d_{4}^{-}+d_{4}^{+}\right)$

Senaryo -10

$\operatorname{Min} \mathrm{Z}=\mathrm{P} 1\left(d_{1}^{+}\right)+\mathrm{P} 2\left(d_{4}^{-}+d_{4}^{+}\right)+\mathrm{P} 3\left(d_{2}^{+}\right)$
Senaryo - 11

$\operatorname{Min} \mathrm{Z}=\mathrm{P} 1\left(d_{2}^{+}\right)+\mathrm{P} 2\left(d_{1}^{+}\right)+\mathrm{P} 3\left(d_{4}^{-}+d_{4}^{+}\right)$

Senaryo - 12

$\operatorname{Min} \mathrm{Z}=\mathrm{P} 1\left(d_{2}^{+}\right)+\mathrm{P} 2\left(d_{4}^{-}+d_{4}^{+}\right)+\mathrm{P} 3\left(d_{1}^{+}\right)$

Senaryo -13

$\operatorname{Min} \mathrm{Z}=\mathrm{P} 1\left(d_{4}^{-}+d_{4}^{+}\right)+\mathrm{P} 2\left(d_{1}^{+}\right)+\mathrm{P} 3\left(d_{2}^{+}\right)$

Senaryo - 14

$\operatorname{Min} \mathrm{Z}=\mathrm{P} 1\left(d_{4}^{-}+d_{4}^{+}\right)+\mathrm{P} 2\left(d_{2}^{+}\right)+\mathrm{P} 3\left(d_{1}^{+}\right)$

$X_{i j}=0$ veya $1 \quad\left(\forall_{i}, \forall_{j}\right)$

$d_{i}^{+}, d_{i}^{-} \geq 0 \quad(\mathrm{i}=1,2,3,4)$

Senaryolara göre oluşturulan matematiksel modellerde kullanilan kisitlar Tablo 33'de belirtilmiştir.

Hedef programlamanın matematiksel modelinin kurulumunda yararlanılacak olan veriler Tablo 32'de verilmiştir.

Senaryolara ilişkin matematiksel modellerin çözüm sonucu elde edilen sapma değerleri, değişken sayısı, kısıt sayısı, çözüm süresi ve seçilen proje sayısı Tablo 34'de belirtilmiştir. Ayrıca her bir senaryo için oluşturulan modelin çözümü sonucu seçilebilecek projelerde Tablo 35'te verilmiştir.

Tablo 30'daki senaryolara ait bilgilere göre seçilebilecek proje sayısı eşit olarak alınmış hedeflere ait kısıtlarda bir dizi değiş̧iklikler baz alınarak modeller kurulmuştur. Kisit ve değişken sayıları modellerle doğru orantılıdır. Senaryolara ilişkin değerlendirmeler aşağıda açıklanmıştır.

Senaryo-1'in model çözüm süresi diğer senaryolara göre daha fazladır. Bunun nedeni bütçe, personel sayısı ve AHS ağırlıklarının mümkün olduğu kadarıyla eşit olarak dağıtılması için hedef kısıtlarının olmasından dolayıdır. Bütçeye ilişkin pozitif sapma değerinin büyük olması, seçilebilecek proje sayısinin fazla olmasindan kaynaklanmaktadır. Personel sayısında ise sapma yoktur. 31 adet yatırım projesi seçimi yapılmıştır. Senaryo-2' de personel sayısında herhangi bir sapma yoktur. Seçilebilecek proje sayısı Senaryo-4, 5, 11, 13 ile aynıdır. VIKOR sapma değeri Senaryo-12, 13, 14 ile aynıdır. Senaryo-3'teki personel sayısında pozitif sapma vardır. AHS sapmasının değeri ise 
Senaryo-1'e göre daha yüksektir. Bütçe sapma değeri Senaryo-4, 5, 9, 10, 11 ile aynıdır. Senaryo4'te göze çarpan personel sayısındaki pozitif sapmanın diğer senaryolara göre yüksek olmasıdır. Senaryo-5'te ise personel sayısinda sapma yoktur. Şayet personel sayısı baz alınarak proje seçilmek isteniyor ise bu senaryo tercih edilebilir. Senaryo-6 en fazla proje seçilen senaryolardan olmasıdır. Bütçede sapma Senaryo-1 ve Senaryo-8 ile ayn olup yüksektir. Senaryo-7'de bütçe sapmasının diğer senaryolara göre en yüksek olması bu senaryonun uygulanabilirliğini azaltmıştır. Şayet proje sayısı baz alınarak seçim yapılırsa en yüksek proje sayısını kapsamaktadır. Senaryo-8'de personel sayısında sapma yoktur. Şayet personel sayısı gözönüne alınarak proje seçilmesi isteniyorsa bu proje seçilebilir. Senaryo-9'da personel sayısı ve bütçe sapmalarında diğer senaryolara göre farklılık bulunmamaktadır. Fakat VIKOR sapma değeri 1'dir. Bu değerle VIKOR sapmasına göre bu senaryo değerlendirilebilir. Çünkü VIKOR'da sapmanın en büyük olması amaçtır. Senaryo-10, Senaryo-9'daki değerlerle aynıdır. Bu değerlere göre bu iki senaryodan biri seçilmek istenirse sonuçlar aynı olacaktır. Senaryo-11'de bütçe sapması yoktur. VIKOR sapmasıda pozitif sapması en büyük değer olduğundan bu senaryo seçilebilir. Senaryo-12'de bütçe sapması diğer senaryolara göre biraz düşük çıkmıştır. Personel sayısında ise sapma yoktur. Senaryo-13'te diğer senaryolar ile sonuçlar yakındır. Bütçe sapması azalma göstermiştir. Bunun nedeni ise seçilebilecek proje sayısının az olmasından kaynaklanmaktadır. Senaryo-14'de personel sayısında sapma yoktur. Bütçe sapmasının olması seçilebilecek proje sayısının arttığını göstermektedir.

Personel sayısına ilişkin en büyük sapma değeri Senaryo-4'tedir. Bunun nedeni modelde personel sayısının 3. öncelikli değerli olarak atanmasından kaynaklanmaktadır. Personel sayısının optimum olduğu senaryolar ise Senaryo-1, Senaryo-2, Senaryo-5, Senaryo 6, Senaryo-8, Senaryo-11 ve Senaryo-12'dir. AHS'ye ilişkin sapma değerlerinin en küçük olması istendiğinden Senaryo-1 en küçük değeri vermektedir.
Tablo 31. Ana Proje ve Alt Proje Açıklaması

\begin{tabular}{|c|c|c|}
\hline Ana Proje & Alt Proje & Açıklama \\
\hline \multirow{5}{*}{ 1. Ana Proje } & 1. Alt Proje & Tezgah Yatırımı \\
\hline & 2. Alt Proje & Taşınabilir Ekipman Yatırımı \\
\hline & 3. Alt Proje & Otomasyon Yatırımı \\
\hline & 4. Alt Proje & Tezgah Yatırımı \\
\hline & 1. Alt Proje & Yazılım Yatırımı \\
\hline \multirow[t]{6}{*}{ 2. Ana Proje } & 2. Alt Proje & Araç Yatırımı \\
\hline & 3. Alt Proje & Test Ekipmanı Yatırımı \\
\hline & 1. Alt Proje & Taşınabilir Ekipman Yatırımı \\
\hline & 2. Alt Proje & Donanım Yatırımı \\
\hline & 3. Alt Proje & Yeni Tesis Yatırımı \\
\hline & 4. Alt Proje & Yeni Tesis Yatırımı \\
\hline \multirow[t]{7}{*}{ 3. Ana Proje } & 5. Alt Proje & Tezgah Yatırımı \\
\hline & 6. Alt Proje & Yazılım Yatırımı \\
\hline & 7. Alt Proje & Test Ekipmanı Yatırımı \\
\hline & 8. Alt Proje & Test Ekipmanı Yatırımı \\
\hline & 9. Alt Proje & Test Ekipmanı Yatırımı \\
\hline & 1. Alt Proje & Test Sahası Yapımı Yatırımı \\
\hline & 2. Alt Proje & Test Ekipmanı Yatırımı \\
\hline \multirow[t]{4}{*}{ 4. Ana Proje } & 3. Alt Proje & Yazılım Yatırımı \\
\hline & 4. Alt Proje & Tezgâh Yatırımı \\
\hline & 5. Alt Proje & Yeni Tesis Yatırımı \\
\hline & 1. Alt Proje & Test Ekipmanı Yatırımı \\
\hline \multirow[t]{3}{*}{ 5. Ana Proje } & 2. Alt Proje & Araç Yatırımı \\
\hline & 3. Alt Proje & Taşınabilir Ekipman Yatırımı \\
\hline & 1. Alt Proje & Tezgâh Yatırımı \\
\hline \multirow{3}{*}{ 6. Ana Proje } & 2. Alt Proje & Yazılım Yatırımı \\
\hline & 3. Alt Proje & Taşınabilir Ekipman Yatırımı \\
\hline & 4. Alt Proje & Test Ekipmanı Yatırımı \\
\hline \multirow[t]{4}{*}{ 7. Ana Proje } & 1. Alt Proje & Tezgâh ve Test Ekipmanı Yatırımı \\
\hline & 1. Alt Proje & Taşınabilir Ekipman Yatırımı \\
\hline & 2. Alt Proje & Tezgâh Yatırımı \\
\hline & 3. Alt Proje & Yazılım Yatırımı \\
\hline \multirow{5}{*}{ 8. Ana Proje } & 4. Alt Proje & Yeni Tesis İçin Ofis Donanımı Yatırımı \\
\hline & 5. Alt Proje & Test Ekipmanı Yatırımı \\
\hline & 6. Alt Proje & Yeni Tesis Yatırımı İçin Tezgâh Yatırımı \\
\hline & 7. Alt Proje & Yeni Tesis Yatırımı \\
\hline & 8. Alt Proje & Araç Yatırımı \\
\hline
\end{tabular}


Tablo 32. Hedef Programlama Veri Çizelgesi

\begin{tabular}{|c|c|c|c|c|c|c|}
\hline Ana Proje & Alt Proje & $\begin{array}{l}\text { Bütçe } \\
\text { (TL) }\end{array}$ & $\begin{array}{c}\text { Personel } \\
\text { SayısI }\end{array}$ & $\begin{array}{c}\text { AHP Ana } \\
\text { Proje Ağırlık } \\
\text { Değerleri }\end{array}$ & $\begin{array}{c}\text { AHP Alt } \\
\text { Proje Ağırlık } \\
\text { Değerleri }\end{array}$ & $\begin{array}{l}\text { VIKOR } \\
\text { Siralama } \\
\text { Değerleri }\end{array}$ \\
\hline \multirow[t]{4}{*}{ 1. Ana Proje } & 1. Alt Proje & 1124583 & 32 & 0,03 & 0,01 & 0,90 \\
\hline & 2. Alt Proje & 232664 & 76 & 0,03 & 0,01 & 0,90 \\
\hline & 3. Alt Proje & 602894 & 8 & 0,03 & 0,01 & 0,90 \\
\hline & 4. Alt Proje & 2111137 & 21 & 0,03 & 0,01 & 0,90 \\
\hline \multirow[t]{3}{*}{ 2. Ana Proje } & 1. Alt Proje & 27004 & 22 & 0,04 & 0,01 & 0,02 \\
\hline & 2. Alt Proje & 134017 & 148 & 0,04 & 0,01 & 0,02 \\
\hline & 3. Alt Proje & 1069249 & 148 & 0,04 & 0,01 & 0,02 \\
\hline \multirow[t]{9}{*}{ 3. Ana Proje } & 1. Alt Proje & 85864 & 38 & 0,12 & 0,01 & 0,73 \\
\hline & 2. Alt Proje & 86000 & 21 & 0,12 & 0,01 & 0,73 \\
\hline & 3. Alt Proje & 42300000 & 227 & 0,12 & 0,01 & 0,73 \\
\hline & 4. Alt Proje & 65149928 & 22 & 0,12 & 0,01 & 0,73 \\
\hline & 5. Alt Proje & 1447170 & 342 & 0,12 & 0,01 & 0,73 \\
\hline & 6. Alt Proje & 245700 & 41 & 0,12 & 0,01 & 0,73 \\
\hline & 7. Alt Proje & 235200 & 41 & 0,12 & 0,01 & 0,73 \\
\hline & 8. Alt Proje & 125800 & 34 & 0,12 & 0,01 & 0,73 \\
\hline & 9. Alt Proje & 137671 & 12 & 0,12 & 0,01 & 0,73 \\
\hline \multirow[t]{5}{*}{ 4. Ana Proje } & 1. Alt Proje & 13381339 & 24 & 0,21 & 0,04 & 0,35 \\
\hline & 2. Alt Proje & 594843 & 110 & 0,21 & 0,04 & 0,35 \\
\hline & 3. Alt Proje & 25431 & 110 & 0,21 & 0,04 & 0,35 \\
\hline & 4. Alt Proje & 1947315 & 110 & 0,21 & 0,04 & 0,35 \\
\hline & 5. Alt Proje & 39978037 & 110 & 0,21 & 0,04 & 0,35 \\
\hline \multirow[t]{3}{*}{ 5. Ana Proje } & 1. Alt Proje & 57435 & 23 & 0,05 & 0,02 & 0,41 \\
\hline & 2. Alt Proje & 46132 & 38 & 0,05 & 0,02 & 0,41 \\
\hline & 3. Alt Proje & 688615 & 35 & 0,05 & 0,02 & 0,41 \\
\hline \multirow[t]{4}{*}{ 6. Ana Proje } & 1. Alt Proje & 7619593 & 143 & 0,27 & 0,07 & 0,12 \\
\hline & 2. Alt Proje & 122723 & 143 & 0,27 & 0,07 & 0,12 \\
\hline & 3. Alt Proje & 2115832 & 143 & 0,27 & 0,07 & 0,12 \\
\hline & 4. Alt Proje & 5475010 & 143 & 0,27 & 0,07 & 0,12 \\
\hline 7. Ana Proje & 1. Alt Proje & 1610662 & 87 & 0,20 & 0,20 & 0,01 \\
\hline \multirow[t]{8}{*}{ 8. Ana Proje } & 1. Alt Proje & 557521 & 28 & 0,09 & 0,01 & 0,27 \\
\hline & 2. Alt Proje & 750125 & 75 & 0,09 & 0,01 & 0,27 \\
\hline & 3. Alt Proje & 239844 & 75 & 0,09 & 0,01 & 0,27 \\
\hline & 4. Alt Proje & 176900 & 76 & 0,09 & 0,01 & 0,27 \\
\hline & 5. Alt Proje & 247306 & 38 & 0,09 & 0,01 & 0,27 \\
\hline & 6. Alt Proje & 685122 & 52 & 0,09 & 0,01 & 0,27 \\
\hline & 7. Alt Proje & 725829 & 128 & 0,09 & 0,01 & 0,27 \\
\hline & 8. Alt Proje & 429268 & 32 & 0,09 & 0,01 & 0,27 \\
\hline
\end{tabular}


Tablo 33. Matematiksel Modellerde Kullanılan Kısitlar

\begin{tabular}{ccccccccc}
\hline Kisitlar & $\begin{array}{c}\text { Kisit- } \\
\text { Kisit- }\end{array}$ & $\begin{array}{c}\text { Kisit- } \\
\mathbf{2}\end{array}$ & $\begin{array}{c}\text { Kisit- } \\
\mathbf{4}\end{array}$ & $\mathbf{4}$ & Hedef Kisıtt-1 & Hedef Kisit1-2 & Hedef Kisiti-3 & Hedef Kisitt-4 \\
\hline Senaryo-1 & $\sqrt{ }$ & $\sqrt{ }$ & $\sqrt{ }$ & $\sqrt{ }$ & $\sqrt{ }$ & $\sqrt{ }$ & $\sqrt{ }$ & \\
Senaryo-2 & $\sqrt{ }$ & $\sqrt{ }$ & $\sqrt{ }$ & $\sqrt{ }$ & $\sqrt{ }$ & $\sqrt{ }$ & & $\sqrt{ }$ \\
Senaryo-3 & $\sqrt{ }$ & $\sqrt{ }$ & $\sqrt{ }$ & $\sqrt{ }$ & $\sqrt{ }$ & $\sqrt{ }$ & $\sqrt{ }$ & \\
Senaryo-4 & $\sqrt{ }$ & $\sqrt{ }$ & $\sqrt{ }$ & $\sqrt{ }$ & $\sqrt{ }$ & $\sqrt{ }$ & $\sqrt{ }$ & \\
Senaryo-5 & $\sqrt{ }$ & $\sqrt{ }$ & $\sqrt{ }$ & $\sqrt{ }$ & $\sqrt{ }$ & $\sqrt{ }$ & $\sqrt{ }$ & \\
Senaryo-6 & $\sqrt{ }$ & $\sqrt{ }$ & $\sqrt{ }$ & $\sqrt{ }$ & $\sqrt{ }$ & $\sqrt{ }$ & $\sqrt{ }$ & \\
Senaryo-7 & $\sqrt{ }$ & $\sqrt{ }$ & $\sqrt{ }$ & $\sqrt{ }$ & $\sqrt{ }$ & $\sqrt{ }$ & $\sqrt{ }$ & \\
Senaryo-8 & $\sqrt{ }$ & $\sqrt{ }$ & $\sqrt{ }$ & $\sqrt{ }$ & $\sqrt{ }$ & $\sqrt{ }$ & $\sqrt{ }$ & \\
Senaryo-9 & $\sqrt{ }$ & $\sqrt{ }$ & $\sqrt{ }$ & $\sqrt{ }$ & $\sqrt{ }$ & $\sqrt{ }$ & & $\sqrt{ }$ \\
Senaryo-10 & $\sqrt{ }$ & $\sqrt{ }$ & $\sqrt{ }$ & $\sqrt{ }$ & $\sqrt{ }$ & $\sqrt{ }$ & & $\sqrt{ }$ \\
Senaryo-11 & $\sqrt{ }$ & $\sqrt{ }$ & $\sqrt{ }$ & $\sqrt{ }$ & $\sqrt{ }$ & $\sqrt{ }$ & & $\sqrt{ }$ \\
Senaryo-12 & $\sqrt{ }$ & $\sqrt{ }$ & $\sqrt{ }$ & $\sqrt{ }$ & $\sqrt{ }$ & $\sqrt{ }$ & & $\sqrt{ }$ \\
Senaryo-13 & $\sqrt{ }$ & $\sqrt{ }$ & $\sqrt{ }$ & $\sqrt{ }$ & $\sqrt{ }$ & $\sqrt{ }$ & & \\
Senaryo-14 & $\sqrt{ }$ & $\sqrt{ }$ & $\sqrt{ }$ & $\sqrt{ }$ & $\sqrt{ }$ & $\sqrt{ }$ & & \\
\hline
\end{tabular}

Tablo 34. HP Çözüm Sonucu Verileri

\begin{tabular}{lccccccc}
\hline HP Model & $\begin{array}{c}\text { Seçilen } \\
\text { Proje } \\
\text { Sayısı }\end{array}$ & $\begin{array}{c}\text { Değişken } \\
\text { Sayısı }\end{array}$ & $\begin{array}{c}\text { Kısıt } \\
\text { Sayısı }\end{array}$ & $\begin{array}{c}\text { Cözzüm } \\
\text { Süresi } \\
\text { (sn) }\end{array}$ & $\begin{array}{c}\text { Hedef 1 - } \\
\text { Sapma }\end{array}$ & $\begin{array}{c}\text { Hedef 2 - } \\
\text { Sapma }\end{array}$ & $\begin{array}{c}\text { Hedef 3 - } \\
\text { Sapma }\end{array}$ \\
\hline Senaryo-1 & 31 & 80 & 91 & 192 & 420777 & 0 & $-0,0001$ \\
Senaryo-2 & 16 & 80 & 91 & 178 & 116275 & 0 & 0,071 \\
Senaryo-3 & 14 & 80 & 93 & 112 & 98964 & 77 & $-0,007$ \\
Senaryo-4 & 16 & 80 & 93 & 114 & 98964 & $-0,007$ & 531 \\
Senaryo-5 & 16 & 80 & 93 & 110 & 0 & 98964 & $-0,007$ \\
Senaryo-6 & 31 & 80 & 93 & 122 & 0 & $-0,0009$ & 420777 \\
Senaryo-7 & 31 & 80 & 91 & 120 & $-0,0009$ & 440683 & 49 \\
Senaryo-8 & 31 & 80 & 91 & 124 & $-0,0009$ & 0 & 420777 \\
Senaryo-9 & 14 & 80 & 93 & 108 & 98964 & 77 & 1 \\
Senaryo-10 & 14 & 80 & 93 & 106 & 98964 & 1 & 77 \\
Senaryo-11 & 16 & 80 & 93 & 108 & 0 & 98964 & 1 \\
Senaryo-12 & 18 & 80 & 93 & 128 & 0 & 0,071 & 151146 \\
Senaryo-13 & 16 & 80 & 93 & 130 & 0,071 & 123363 & 6 \\
Senaryo-14 & 18 & 80 & 93 & 134 & 0,071 & 0 & 151146 \\
\hline
\end{tabular}

VIKOR yönteminde ise sapma değerlerinin en büyük olması istendiğinden Senaryo-9, Senaryo-10 ve Senaryo-11 en büyük değeri göstermektedir. Senaryo-1, Senaryo-6 ve Senaryo-8 seçilebilir yatırım projesi sayısı açısından en çok projeyi kapsamaktadır. Senaryo-3, Senaryo-9 ve Senaryo10 ise en az sayıda seçilebilecek projeyi vermektedir. 
Tablo 35. HP Çözümü Sonucu Seçilebilecek Projeler

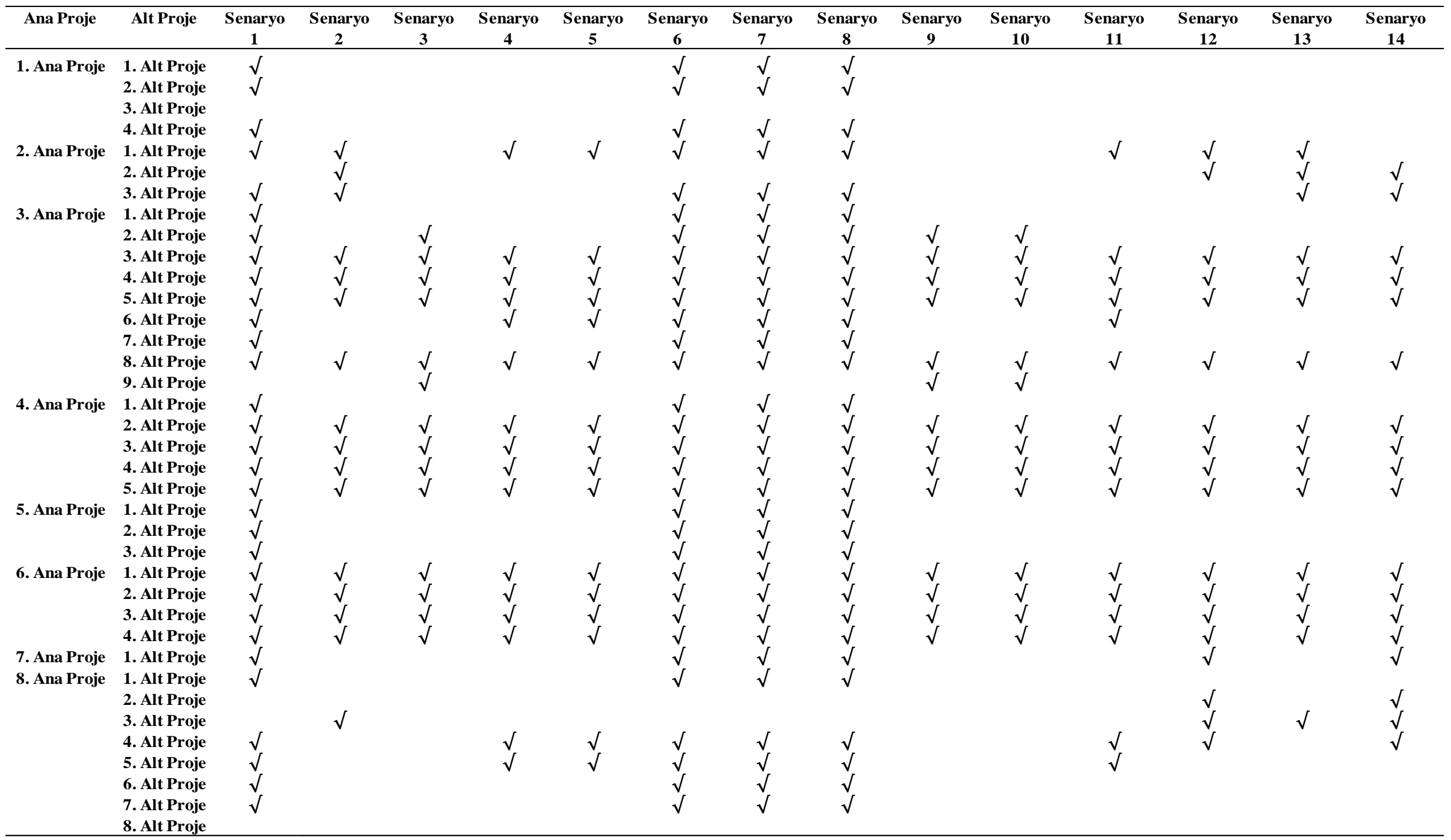




\section{Sonuç}

Savunma sanayi, yapısı ve vazifesi gereği diğer sanayi sektörleriyle bir takım benzerliğinin yanı sıra birçok farklılıklar da göstermektedir. Savunma sanayinin öncelikli hedefi, diğer sektörlerde olduğu gibi kâr maksimizasyonu ya da yüksek değere sahip firmalar oluşturmak değildir. Bununla beraber, sektördeki firmaların, ülkemiz ekonomisine olumlu ya da olumsuz etkileri olduğu da görülmektedir. Savunma sanayinin ülke ekonomilerine olumlu ya da olumsuz katkısı olduğu yönünde farklı görüşler bulunmaktadır.

Ülkeler ve işletmeler için yatırım projelerinin önemi büyüktür. $\mathrm{Bu}$ nedenle yatırım projesine yatırım yapma kararı verilmeden önce gerçekçi bir şekilde yapılacak olan yatırım projesi seçimi ile mevcut belirsizliklerin büyük bir bölümü ortadan kaldırılarak karar vermede kolaylık sağlanmış olacaktır. Günümüzde firmalar yatırım yapmak istediklerinde birçok kriteri göz önüne bulundurmak zorundadır. Yatırıma başlamadan önce maliyet ve zaman açısından en uygun kararın verilmesi, işletmenin rekabet üstünlüğünü muhafaza etmesi veya rekabet üstünlüğü sağlaması için büyük önem arz etmektedir. Yatırımcıların karşılaştığı en büyük sorun sınırlı kaynakları ekonomik bir şekilde kullanamayarak kârlı yatırımlar yapamamalarıdır. Yatırımcıların vereceği kararın sağlıklı olması için, karar sürecinde gerekli olan bilgilerin doğru, güvenilir, hızlı olması ve sağlam bir kaynaktan gelmesi gerekir. $\mathrm{Bu}$ bilgi ve verilerin uygun yöntemler yardımıyla doğru bir şekilde değerlendirilip analiz edilmesi ile yatırımcıya sayısal verilerle birlikte alternatif senaryoların hızlı bir şekilde sunulabilmesini sağlamaktadır. Böylece yatırımcı kendisi için en uygun olan yatırım projesini kolayca belirleyebilecektir.

$\mathrm{Bu}$ çalışma, hava savunma sanayinde faaliyet gösteren şirketin yöneticilerinin, belirlenmiş olan yatırım projeleri arasından seçim yapma kararını kapsamaktadır. Karar verme, 8 ana proje ve ana projeler altındaki 37 alt projenin arasından en uygun olanının seçimi üzerinde gerçekleştirilmiştir.

Çalışmada, çok kriterli karar verme yöntemlerinden AHS, VIKOR yöntemleri ve Hedef Programlama kullanılarak karar vericilerin tatminkâr çözüme ulaşması amaçlanmıştır. Yatırım projelerini önceliklendirmek için belirlenen kriterler tespit edilirken uzman kişilerle yapılan anket verileri kullanılarak AHS yöntemi ile kriter ağırlıkları hesaplanmıştır. AHS yönteminden bulunan ağırlıklar VIKOR ve hedef programlamada kullanılmıştır. Ayrıca VIKOR yöntemi ağırlıkları da Hedef Programlama da kullanılmıştır. AHS ve VIKOR yöntemlerine ilișkin hesaplamalar Excel programı ile hedef programlama matematiksel modeli ise ILOG CPLEX Studio IDE programında kodlanarak, CPLEX çözücüsüyle çözümlenmiştir.

$\mathrm{Bu}$ çalışma yatırım projesi seçimi kapsamında özgün bir niteliğe sahiptir. Uygulamada kullanılan yöntemler sadece yapılan firmaya has olmayıp başka yatırım projelerinin seçimi içinde kullanılabilir. Projelerin seçimi matematiksel işlemler ve modeller ile yapıldığından karar vericilere projeye yatırımın seçilebileceği ile ilgili değerler vermektedir. Daha sonraki çalışmalarda işletme tarafından yatırım yapılması düşünülen diğer projelere ilișkin ve ayrıca diğer sektörlerde de yatırım yapmayı planlayan işletmelerde de bu çalışmadaki matematiksel modeller kullanılarak yatırım projesi seçimi yapılabilir. Daha farklı kriterler ve yatırım projesine bağlı farklı hedefler ve farklı özel kısıtlar kullanılabilir. Yatırım projesi seçimi problemine benzer çok ölçütlü karar verme problemlerinde, karar vericilere ANP, TOPSIS, ELECTRE, PROMETHEE gibi diğer çok ölçütlü karar verme yöntemlerinin uygulanması da önerilebilir. Böylece karmaşık yapıda bulunan problemlerde etkin seçim yapmak mümkün olacaktır.

\section{Kaynaklar}

[1] B. Karaman and H. Çerçioğlu, "0-1 Hedef Programlama Destekli Bütünleşik AHPVIKOR Yöntemi: Hastane Yatırımı Projeleri Seçimi," Gazi Üniversitesi Mühendislik Mimarlık Fakültesi Dergisi, 30 (4), 567-576, 2015.

[2] T.L. Satty, Fundamentals of Decision Making and Priority Theory with The Analytic Hierarchy Process. Pitssburgh: RWS Publications, 1994.

[3] S. Aytürk, "Askeri savunma sistemlerinde analitik hiyerarşi ve analitik şebeke prosesi ile hafif makineli tüfek seçimi," Gazi Üniversitesi, Fen Bilimleri Enstitüsü, (Yayınlanmamış Yüksek Lisans Tezi), 2006.

[4] E.A. Göze, "Analitik ağ süreci ile sürdürülebilir bir üçüncü parti lojistik servis sağlayıcı seçimi," Yıldız Teknik Üniversitesi, Fen Bilimleri Enstitüsü, Yüksek Lisans Tezi, 2008. 
[5] F.Y. Partovi, "Determining What to Bechmark: An Analytic Hierarchy Process Approach," International Journal of Operation and Production Management, 14 (6), 25-39, 1994.

[6] T.L. Saaty, "How to Make a Decision: The Analytic Hierarchy Process," European Journal of Operational Research, 48, 9-26, 1990.

[7] R.S. Russell and B.W. Taylor, Operations Management 4th Edition. New Jersey: Prentice Hall, 2003.

[8] H. Y1lmaz, "Ürün Tasarımında Kalite Fonksiyon Yayılımı (KFY) ve Analitik Hiyerarşi Süreci (AHS) Yöntemleriyle Ürün Optimizasyonu: Seramik Lavabo Örneği," İzmir Yüksek Teknoloji Enstitüsü, Fen Bilimleri Enstitüsü, Yüksek Lisans Tezi, 2009.

[9] T.L. Saaty, The Analytic Hierarchy Process. McGraw-Hill, USA, 1980.

[10] P.L. Yu, "A Class of Solutions for Group Decision Problems," Management Science, 19, 936-946, 1973.

[11] M. Zeleny, Multiple Criteria Decision Making. New York: Mc-Graw-Hill, 1982.

[12] S. Opriovic and G.H. Tzeng, "Compromise Solution by MCDM Methods: A Comparative Analysis of VIKOR and TOPSIS," European Journal of Operational Research, 156, 445-455, 2004.

[13] S. Opricovic and G.H. Tzeng, "Extended VIKOR method in comparison with outranking methods," European Journal of Operational Research, 178, 514-529, 2007.

[14] M. Tamiz and D.F. Jones, "Interactive Frameworks for Investigation of Goal Programming Models: Theory and Practice," Journal of Multi-Criteria Decision Analysis, 6, 52-60, 1997.

[15] A. Charnes, W.W. Cooper and R. Ferguson, "Optimal Estimation of Executive Compensation by Linear Programming," Management Science, 1, 138-151, 1955.

[16] A. Charnes and W.W. Cooper, Management Models and Industrial Applications of Linear Programming. New York: Wiley, 1961.

[17] S.M. Lee, Goal Programming for Decision Analysis. Philadelphia: Auerbach, 1972.

[18] .P. Ignizio, Goal Programming and Extensions. Lexington Mass: Heath.MA: Lexington Books, 1976.

[19] H.M. Weingartner, "Criteria for Programming Investment Project Selection," The Journal of Industrial Economics, 15 (1), 65-76, 1966.

[20] K. Mukherjee and A. Bera, "Application of Goal Programming in Project Selection Decision-A Case Study from The Indian Coal Mining
Industry," European Journal of Operational Research, 82 (1), 18-25, 1995.

[21] R. Santhanamt and J. Kyparisis, "A Multiple Criteria Decision Model for Information System Project Selection," Computers and Operations Research, 22 (8), 807-818, 1995.

[22] G.C. Kim and J. Emery, "An Application of Zero-One Goal Programming in Project Selection and Resource Planning-A Case Study from the Woodward Governor Company," Computers and Operations Research, 27 (14), 1389-1408, 2000.

[23] J.W. Lee and S.H. Kim, "Using Analytic Network Process and Goal Programming for Interdependent Information System Project Selection," Computers and Operations Research, 27, 367-382, 2000.

[24] M.A. Badri, D. Davis and D. Davis, "A Comprehensive 0-1 Goal Programming Model for Project Selection," International Journal of Project Management, 19, 243-252, 2001.

[25] S. Yavuz and T.A. Captain, "Making Project Selection Decisions: A Multi-Period Capital Budgeting Problem," International Journal of Industrial Engineering, 9 (3), 301-310, 2002.

[26] H. Aras, Ş. Erdoğmuş and E. Koç, "MultiCriteria Selection for A Wind Observation Station Location Using Analytic Hierarchy Process," Renewable Energy, 29, 1383-1392, 2004.

[27] E.W.L. Cheng and H. Li, "Analytic Network Process Applied to Project Selection," J. Constr. Eng. Management, 131 (4), 459-466, 2005.

[28] G.H. Tzeng, C.W. Lin and S. Opricovic, "MultiCriteria Analysis of Alternative-Fuel Buses for Public Transportation," Energy Policy, 33, 1373-1383, 2005.

[29] L. Dimova, P. Sevastianov and D. Sevastianov "MCDM in a Fuzzy Setting: Investment Projects Assessment Application," Int. J. Production Economics, 100, 10-29, 2006.

[30] C. Yang and T. Wang, "VIKOR Method Analysis of Interactive Trade in PolicyMaking," The Business Review, 6 (2), 77-85, 2006.

[31] H. Liu and T. Yan, "Bidding-evaluation of construction projects based on VIKOR method", In Automation and Logistics, August 2007, IEEE International Conference on, 1778-1782.

[32] B.B. Tripathy and M.P. Biswal, "A Zero-One Goal Programming Approach for Project Selection," Journal of Information and Optimization Sciences, 28 (4), 619-626, 2007.

[33] I. Kim, S. Shin, Y. Choi, N.M. Thang, E.R. Ramos and W.J. Hwang, "Development of A Project Selection Method on Information 
System Using ANP And Fuzzy Logic," International Journal of Computer, Electrical, Automation, Control and Information Engineering, 3 (5), 2009.

[34] İ.F. Gülenç and G.A. Bilgin, "Yatırım Kararları İçin Bir Model Önerisi," Öneri, 9 (34), 97-107, 2010.

[35] P. Aragonés-Beltrán, F. Chaparro-Gonzalez, J.P. Pastor-Fernando and F. Rodriguez-Pozo, "An ANP-Based Approach for The Selection of Photovoltaic Solar Power Plant Investment Projects," Renewable and Sustainable Energy Reviews, 14, 249-264, 2010.

[36] J.R. San Cristóbal, "Multi-Criteria DecisionMaking in The Selection of a Renewable Energy Project in Spain: The VIKOR method," Renewable Energy, 36, 498-502, 2011.

[37] S. Nandi, S. Paul and M. Phadtare, "An AHPBased Construction Project Selection Method," Decision, 38 (1), 91-118, 2011.

[38] A. Kuru and B. Akın, "Entegre Yönetim Sistemlerinde Çok Kriterli Karar Verme Tekniklerinin Kullanımına Yönelik Yaklaşımlar ve Uygulamalar1," Öneri, 10 (38), 129-144, 2012.

[39] S. Ebrahimnejad, S.M. Mousavi, R. TavakkoliMoghaddam, H. Hashemi and B. Vahdani, "A Novel Two-Phase Group Decision Making Approach for Construction Project Selection in A Fuzzy Environment," Applied Mathematical Modelling, 36, 4197-4217, 2012.

[40] B. Bilgen and M. Şen, "Project Selection Through Fuzzy Analytic Hierarchy Process and A Case Study on Six Sigma Implementation in An Automotive Industry," Production Planning and Control, 23 (1), 2-25, 2012.

[41] S. Kaplan and F. Arıkan, "Hava Savunma Sektörü Tezgâh Yatırım Projelerinin Bulanık Analitik Hiyerarşi Prosesi ile Değerlendirilmesi," Havacılık ve Uzay Teknolojileri Dergisi, 5 (3), 23-33, 2012.

[42] P. Aragonés-Beltrán, F. Chaparro-Gonzalez and J.P. Pastor-Fernando, "An AHP (Analytic Hierarchy Process)/ANP (Analytic Network Process)-Based Multi-Criteria Decision Approach for The Selection Of Solar-Thermal Power Plant Investment Projects," Energy, 66, 222-238, 2014.

[43] S. Dozic and M. Kalic, "An AHP Approach to Aircraft Selection Process," Transportation Research Procedia, 3, 165-174, 2014.

[44] N. Bedir and T. Eren, "AHP-PROMETHEE Yöntemleri Entegrasyonu ile Personel Seçim Problemi: Perakende Sektöründe Bir Uygulama," Social Sciences Research Journal, 4, 46-58, 2015.
[45] P. Pangsri, "Application of The Multi Criteria Decision Making Methods for Project Selection," Universal Journal of Management, 3 (1), 15-20, 2015.

[46] K. Salehi, "A Hybrid Fuzzy MCDM Approach for Project Selection Problem," Decision Science Letters, 4, 109-116, 2015.

[47] T. Eren and E.H. Özder, "Çok Ölçütlü Karar Verme Yöntemleri ile Bir İçecek Firması için Tedarikçi Seçimi”, In 4th International Symposium on Innovative Technologies in Engineering and Science (ISITES2016), 3-5 November 2016, Alanya/Antalya-Turkey.

[48] M. Hamurcu and T. Eren, "A Multicriteria Decision-Making for Monorail Route Selection in Ankara," International Journal of Industrial Electronics and Electrical Engineering, 4 (5), 121-125, 2016.

[49] Ş. Cihan, E. Ayan, T. Eren, T. Topal and E.K. Yıldırım, "Çok Ölçütlü Karar Verme Yöntemleri ile Ekokardiyografi Cihazı Seçiminin Yapılmas1," HSP, 4 (1), 41-49, 2017.

[50] Ş. Gür, M. Hamurcu and T. Eren, "Ankara'da Monoray Projelerinin Analitik Hiyerarşi Prosesi ve 0-1 Hedef Programlama ile Seçimi," Pamukkale Üniversitesi Mühendislik Bilimleri Dergisi, 23 (4), 437-443, 2017.

[51] M. Taş, Ş.N. Özlemiş, M. Hamurcu and T. Eren, "Analitik Hiyerarşi Prosesi ve Hedef Programlama Karma Modeli Kullanılarak Monoray Projelerinin Seçimi," Harran Üniversitesi Mühendislik Dergisi, 2, 24-42, 2017.

[52] M. Hamurcu and T. Eren, "Sürdürülebilir Kent İçi Ulaşım İçin Bulanık AHP Tabanlı VIKOR Yöntemi ile Proje Seçimi”, International Conference on Advanced Engineering Technologies (ICADET 2017), 21-23 Eylül 2017, 874-885, Bayburt, Türkiye.

[53] B. Uçakcioğlu and T. Eren, "Hava Savunma Sanayii Yatırım Projesi Seçiminde Çok Ölçütlü Karar Verme ve Hedef Programlama", 37. Yöneylem Araştırması ve Endüstri Mühendisliği Ulusal Kongresi, 5-7 Temmuz 2017, 60, İstanbul, Türkiye.

[54] M. Hamurcu and T. Eren, "Bulanık ANP Kullanılarak Raylı Sistem Projelerinin Önceliklendirilmesi”, Transist 10. Uluslararas1 Ulaşım Teknolojileri Sempozyumu ve Fuarı, 24 Kasım 2017, 89-97, İstanbul, Türkiye. 